University of Montana

ScholarWorks at University of Montana

Numerical Terradynamic Simulation Group

Publications

Numerical Terradynamic Simulation Group

3-2011

\title{
China's terrestrial carbon balance: Contributions from multiple global change factors
}

Hanqin Tian

Auburn University Main Campus

Jerry M. Melillo

Chaoqun Lu

Auburn University Main Campus

David W. Kicklighter

The University of Montana

Mingliang Liu

See next page for additional authors

Follow this and additional works at: https://scholarworks.umt.edu/ntsg_pubs

Let us know how access to this document benefits you.

\section{Recommended Citation}

Tian, H., et al. (2011), China's terrestrial carbon balance: Contributions from multiple global change factors, Global Biogeochem. Cycles, 25, GB1007, doi:10.1029/2010GB003838

This Article is brought to you for free and open access by the Numerical Terradynamic Simulation Group at ScholarWorks at University of Montana. It has been accepted for inclusion in Numerical Terradynamic Simulation Group Publications by an authorized administrator of ScholarWorks at University of Montana. For more information, please contact scholarworks@mso.umt.edu. 


\section{Authors}

Hanqin Tian, Jerry M. Melillo, Chaoqun Lu, David W. Kicklighter, Mingliang Liu, Wei Ren, Xiaofeng Xu, Guangsheng Chen, Chi Zhang, Shufen Pan, Jiyuan Liu, and Steven W. Running 


\title{
China's terrestrial carbon balance: Contributions from multiple global change factors
}

\author{
Hanqin Tian, ${ }^{1,2}$ Jerry Melillo, ${ }^{3}$ Chaoqun Lu, ${ }^{1,2}$ David Kicklighter, ${ }^{3}$ Mingliang Liu,,${ }^{1,2}$ \\ Wei Ren, ${ }^{1,2}$ Xiaofeng Xu, ${ }^{1,2}$ Guangsheng Chen, ${ }^{1,2}$ Chi Zhang, ${ }^{1,2}$ Shufen Pan, ${ }^{1,2}$ \\ Jiyuan Liu, ${ }^{4}$ and Steven Running ${ }^{5}$ \\ Received 2 April 2010; revised 10 October 2010; accepted 31 January 2011; published 31 March 2011.
}

[1] The magnitude, spatial, and temporal patterns of the terrestrial carbon sink and the underlying mechanisms remain uncertain and need to be investigated. China is important in determining the global carbon balance in terms of both carbon emission and carbon uptake. Of particular importance to climate-change policy and carbon management is the ability to evaluate the relative contributions of multiple environmental factors to net carbon source and sink in China's terrestrial ecosystems. Here the effects of multiple environmental factors (climate, atmospheric $\mathrm{CO}_{2}$, ozone pollution, nitrogen deposition, nitrogen fertilizer application, and land cover/land use change) on net carbon balance in terrestrial ecosystems of China for the period 1961-2005 were modeled with newly developed, detailed historical information of these changes. For this period, results from two models indicated a mean land sink of $0.21 \mathrm{Pg} \mathrm{C}$ per year, with a multimodel range from 0.18 to $0.24 \mathrm{Pg} \mathrm{C}$ per year. The models' results are consistent with field observations and national inventory data and provide insights into the biogeochemical mechanisms responsible for the carbon sink in China's land ecosystems. In the simulations, nitrogen deposition and fertilizer applications together accounted for 61 percent of the net carbon storage in China's land ecosystems in recent decades, with atmospheric $\mathrm{CO}_{2}$ increases and land use also functioning to stimulate carbon storage. The size of the modeled carbon sink over the period 1961-2005 was reduced by both ozone pollution and climate change. The modeled carbon sink in response to per unit nitrogen deposition shows a leveling off or a decline in some areas in recent years, although the nitrogen input levels have continued to increase.

Citation: Tian, H., et al. (2011), China's terrestrial carbon balance: Contributions from multiple global change factors, Global Biogeochem. Cycles, 25, GB1007, doi:10.1029/2010GB003838.

\section{Introduction}

[2] The magnitude, spatial and temporal patterns of terrestrial carbon sinks and sources remain far from certain and need to be further investigated [Denman et al., 2007]. However, the real challenge is understanding the processes responsible for net sources and sinks of terrestrial carbon [Houghton, 2007]. China has been shown to be important in

\footnotetext{
${ }^{1}$ Ecosystem Dynamics and Global Ecology Laboratory, School of Forestry and Wildlife Sciences, Auburn University, Auburn, Alabama, USA.

${ }^{2}$ International Center for Climate and Global Change Research, Auburn University, Auburn, Alabama, USA.

${ }^{3}$ The Ecosystem Center, Marine Biological Laboratory, Woods Hole, Massachusetts, USA.

${ }^{4}$ Institute of Geographical Sciences and Natural Resources Research, Chinese Academy of Sciences, Beijing, China.

${ }^{5}$ College of Forestry and Conservation, University of Montana, Missoula, Montana, USA.

Copyright 2011 by the American Geophysical Union. 0886-6236/11/2010GB003838
}

determining the global carbon balance in terms of both carbon emission [Levine and Aden, 2008] and carbon uptake [Piao et al., 2009]. In 2006, China was ranked as the world's largest $\mathrm{CO}_{2}$ emitter due to fossil fuel consumption and cement production, surpassing the United States for the first time [Boden et al., 2009]. A wide range of approaches has been used to estimate the carbon sequestration capacity in China's terrestrial ecosystems over recent decades [Houghton and Hackler, 2003; Pan et al., 2004; Huang and Sun, 2006; Fang et al., 2007; Piao et al., 2009], but none of these studies has performed a thorough exploration of how multiple environmental factors have contributed to and shaped the current terrestrial carbon sink from the spatial and temporal perspectives.

[3] Of particular importance to climate-change policy and carbon management is the ability to quantify the relative contributions of multiple environmental factors to net carbon source and sink behavior [Heimann and Reichstein, 2008]. For millennia, the Chinese people have cut forests, plowed up grasslands, drained wetlands, channelized waterways and altered the landscape in many other ways in pursuit 
of food, fuel and fiber, for a population that is now the world's largest at more than 1.3 billion [Houghton and Hackler, 2003; Liu and Tian, 2010]. Over the last half of the 20th century and particularly in recent decades, China's terrestrial ecosystems have been experiencing a complex set of dramatic changes in climate [Chen et al., 2006], chemical composition of the atmosphere and precipitation [Felzer et al., 2005; Lu and Tian, 2007; Ren et al., 2007a, 2007b], and land use [Liu et al., 2005b; Liu and Tian, 2010]. While a wide range of studies highlight the significance of these environmental changes to the terrestrial carbon cycle across the globe [Ciais et al., 2005; Magnani et al., 2007; Sitch et al., 2007; Kicklighter et al., 1999; Houghton and Hackler, 2003], little is known about how concurrent changes of all of them have affected the carbon-sequestration capacity of China's terrestrial ecosystems.

[4] Here we use two process-based ecosystem/ biogeochemical models, the Terrestrial Ecosystem Model (TEM) [Melillo et al., 1993; Felzer et al., 2005] and the Dynamic Land Ecosystem Model (DLEM) [Ren et al., 2007a, 2007b; Liu et al., 2008; Tian et al., 2008, 2010a, $2010 \mathrm{~b}$ ], in conjunction with newly developed spatial data of the major environmental factors to dynamically simulate changes in net carbon storage in China's land ecosystems for the period 1961-2005.

\section{Model Simulation and Input Data}

[5] Gridded data $(10 \mathrm{~km} \times 10 \mathrm{~km})$ on six major determinants of the terrestrial carbon sink are used in a series of factorial simulation experiments with the two process-based terrestrial ecosystem models to evaluate the relative roles of climate change, increasing atmospheric $\mathrm{CO}_{2}$, ozone pollution, nitrogen $(\mathrm{N})$ deposition, nitrogen fertilizer application and land cover and land use change (LCLUC) on net sources and sinks of carbon in terrestrial ecosystems of China for the period from 1961 to 2005. Because contemporary carbon and nitrogen dynamics in terrestrial ecosystems may be influenced by legacy effects of previous environmental conditions, especially LCLUC [e.g., Houghton et al., 1983; Compton and Boone, 2000; Goodale and Aber, 2001; Tian et al., 2003; Latty et al., 2004; Smith, 2005; Zarin et al., 2005], and dramatic changes in land cover and use are known to have occurred in China during the first half of the 20th century [Liu and Tian, 2010], we reconstructed historical trends in land cover and use, climate and atmospheric chemistry back to 1900 and simulated terrestrial carbon and nitrogen dynamics from 1901 to 2005 . In section 2.1, we first provide brief descriptions of the two process-based models and compare how they estimate the terrestrial carbon balance in China. We then describe the development of the gridded time series input data sets followed by a description of the factorial simulation experiments. Finally, we assess the credibility of the models by comparing site-level model estimates with field estimates of net ecosystem exchange measured at six sites. Additional model validation can be found in Text S1.

\footnotetext{
${ }^{1}$ Auxiliary materials are available in the HTML. doi:10.1029/ $2010 \mathrm{~GB} 003838$
}

\subsection{Model Description}

\subsubsection{Terrestrial Ecosystem Model}

[6] The Terrestrial Ecosystem Model (TEM) is a processbased model that uses spatially referenced information on atmospheric chemistry, climate, elevation, soils, and land cover to estimate monthly carbon, nitrogen, and water fluxes and pool sizes in terrestrial ecosystems. The TEM is welldocumented and has been used to examine patterns of terrestrial $\mathrm{C}$ dynamics across the globe, including how they are influenced by multiple factors such as $\mathrm{CO}_{2}$ fertilization, climate change, food crop and biofuels production, pastures, wildfire and ozone pollution [e.g., Melillo et al., 1993, 2009; Tian et al., 1998, 2003; McGuire et al., 2001, 2004; Felzer et al., 2004, 2005, 2007; Euskirchen et al., 2006; Zhuang et al., 2006; Balshi et al., 2007, 2009; Sokolov et al., 2008; Galford et al., 2011]. For this study, we used a version of TEM that has been modified from Felzer et al. [2004] to include the influence of permafrost dynamics [Euskirchen et al., 2006], atmospheric nitrogen deposition, nitrogen fixation, and the leaching of carbon and nitrogen (dissolved organic carbon, dissolved organic nitrogen, nitrate) to neighboring river networks on terrestrial carbon dynamics. To simulate the effects of nitrogen deposition, $\mathrm{NH}_{\mathrm{X}}$ and $\mathrm{NO}_{Y}$ from prescribed atmospheric sources are added to the appropriate available nitrogen pool (ammonium or nitrate) within TEM for potential uptake by microbes and vegetation. Dissolved organic carbon (DOC) and nitrogen (DON) are assumed to be produced by the incomplete decomposition of soil organic matter (SOM). In addition to atmospheric inputs, nitrate is produced from simulated nitrification in grassland, shrubland and tropical forest ecosystems. Nitrogen fixation is simulated based on the algorithms of Cleveland et al. [1999] adapted to a monthly resolution with the nitrogen added to either the vegetation structural nitrogen pool or the soil organic nitrogen pool based on the ecosystem partitioning described by Cleveland et al. [1999]. Leaching losses of DOC, DON and nitrate are associated with water yield from the ecosystem. The TEM is calibrated to sitespecific field data [McGuire et al., 1995; Clein et al., 2002] and extrapolated across the study area based on spatially explicit time series data.

\subsubsection{Dynamic Land Ecosystem Model}

[7] The Dynamic Land Ecosystem Model (DLEM) is a highly integrated process-based terrestrial ecosystem model that simulates daily carbon, water and nitrogen cycles as influenced by changes in atmospheric chemistry $\left(\mathrm{CO}_{2}\right.$, ozone concentration and nitrogen deposition), climate, land cover and land use change and other disturbances (fire, hurricane, and harvest). The DLEM is well-documented and has been extensively applied to study the terrestrial carbon, water and nitrogen cycles across the globe [e.g., Chen et al., 2006; Ren et al., 2007a, 2007b, 2011; Zhang et al., 2007; Liu et al., 2008; Tian et al., 2008, 2010a, 2010b].

[8] The DLEM includes five core components: (1) biophysics; (2) plant physiology; (3) soil biogeochemistry; (4) dynamic vegetation; and (5) land use, disturbance and land management. The biophysical component includes the instantaneous exchanges of energy, water, and momentum with the atmosphere, which involves micrometeorology, canopy physiology, soil physics, radiative transfer, water and energy flow, and momentum movement. The plant 
physiology component in DLEM simulates major physiological processes such as photosynthesis, respiration, carbohydrate allocation among various organs (root, stem and leaf), nitrogen uptake, transpiration, phenology, etc. The component of soil biogeochemistry simulates mineralization, nitrification/denitrification, decomposition and fermentation so that DLEM is able to estimate simultaneous emissions of multiple trace gases $\left(\mathrm{CO}_{2}, \mathrm{CH}_{4}\right.$ and $\left.\mathrm{N}_{2} \mathrm{O}\right)$. In this study, we did not involve the dynamic vegetation component of the model since land cover was prescribed by a spatially explicit time series data set. The DLEM also emphasizes the water, carbon and nitrogen cycles in managed ecosystems including cropland, forest plantations, and pastures.

[9] This model has been calibrated using various field observational data [Ren et al., 2007b; Tian et al., 2010a, $2010 \mathrm{~b}$ ]. We determined the reasonable ranges of key parameters through literature review. Within these ranges, DLEM has been parameterized according to the observed carbon, water and nitrogen fluxes and pool sizes from the field observation sites of Chinese Ecosystem Research Network (CERN) and other previous studies. The sites adopted for calibration cover almost all of the plant functional types and crop types identified by the contemporary vegetation map in China. The simulation results have also been evaluated with independent field observational data, inventory data and regional estimations from other models and remote sensing tools [Ren et al., 2007a, 2007b; Liu et al, 2008; Tian et al., 2008, 2010a, 2010b].

[10] Unlike TEM, which represents food crops with a generic crop type [Felzer et al., 2004], the DLEM considers several crop types in its simulations including soybean, winter wheat, spring wheat, rice, corn, and barley. For each crop, we specify an appropriate cropping system to represent the crop rotations and crop phenology in addition to cropspecific parameterizations [Ren et al., 2011]. The related plant physiological and biogeochemical processes such as photosynthesis, autotrophic respiration and decomposition within an agroecosystem are simulated in the same way as natural vegetation and depend on the biophysical and biochemical properties (e.g., temperature, soil moisture, soil texture, $\mathrm{pH}$ etc.) of the ecosystem. With harvest, a proportion of carbon is transferred from vegetation to an agricultural product pool where it is assumed to decompose within a year and the rest of the carbon is assumed to be left as residue in the fields (see Text $\mathrm{S} 1$ ). Since most crop biomass is removed through harvest, only change in soil carbon stock is accounted in this study to estimate net carbon exchange for cropland. Prescribed crop management practices, indicated by input data sets (see Text S1), modify the effects of these biophysical and biochemical properties by alleviating nitrogen limitations with the application of nitrogen fertilizers, determining the length of the growing season with harvest schedules and crop rotation (e.g., single, double and triple cropping system), and transferring of carbon from vegetation to soils by specifying the relative proportion of crop biomass harvested. In addition, irrigation is assumed to occur when the soil moisture of the top layer of irrigated croplands (prescribed from an irrigation distribution map [Ren et al., 2011]) drops to $30 \%$ of the maximum available water (i.e., field capacity minus wilting point) during the growing season. We assume that the irrigation would continue until the soil moisture arrives at field capacity. The effects of tillage practices on the decomposition rates of soil organic matter are not considered in our simulations in this study, but may be important for the soil carbon budget [ $\mathrm{Lu}$ et al., 2009; Galford et al., 2011].

\subsubsection{Comparison of Model Features for Estimating Carbon Balance}

[11] Terrestrial carbon balance depends on the net exchange of carbon dioxide, methane, volatile organic carbon between land and the atmosphere and the net exchange of dissolved inorganic carbon, dissolved organic carbon and particulate carbon between land and nearby river networks [Chapin et al., 2006]. Because the fluxes of carbon dioxide between land and the atmosphere dominate carbon fluxes to/ from land ecosystems, terrestrial carbon balance has mostly been determined from model estimates of net carbon dioxide exchange (NCE) [e.g., McGuire et al., 2001] or field estimates of net ecosystem exchange (NEE) [e.g., Baldocchi, 2003]. Both TEM and DLEM have attempted to improve the representation of terrestrial carbon balance by simulating some of the other carbon fluxes in addition to NCE: TEM simulates DOC leaching (LCHDOC) from land ecosystems to river networks; and DLEM simulates methane $\left(\mathrm{CH}_{4}\right)$ emissions. Thus, the models estimate net ecosystem carbon balance (NECB) in slightly different ways. In both TEM and DLEM, the uptake of atmospheric carbon dioxide by vegetation during photosynthesis is represented by gross primary production (GPP). Carbon dioxide is returned to the atmosphere from the autotrophic respiration of plants $\left(R_{A}\right)$ and heterotrophic respiration $\left(\mathrm{R}_{\mathrm{H}}\right)$ associated with decomposition. Net primary production (NPP) is calculated as the difference between GPP and $\mathrm{R}_{\mathrm{A}}$. Net ecosystem production (NEP) is calculated as the difference between NPP and $R_{H}$. Both models also attempt to include the influence of carbon fluxes associated with the conversion of natural areas to agriculture land $\left(\mathrm{E}_{\mathrm{C}}\right)$ and the consumption of agricultural and wood products $\left(\mathrm{E}_{\mathrm{P}}\right)$ on NCE (see Text S1). Thus, in this study, NCE and NECB are calculated as follows:

$$
\begin{gathered}
\text { TEM and DLEM }: \text { NCE }=\text { NEP }-\mathrm{E}_{\mathrm{C}}-\mathrm{E}_{\mathrm{P}} \\
\text { TEM }: \text { NECB }=\text { NCE }- \text { LCHDOC } \\
\text { DLEM }: \text { NECB }=\text { NCE }- \text { CH4 }
\end{gathered}
$$

A positive value of NECB represents a gain of carbon by terrestrial ecosystems (i.e., carbon sequestration) whereas a negative value represents a loss of carbon from the ecosystem. Because field estimates of NEE do not include the carbon fluxes associated with the decomposition of product pools simulated by the models, NEE estimates are most comparable to model NEP estimates [e.g., Amthor et al., 2001]. However, NEE estimates do not represent carbon balance defined in this study, but the net exchange of carbon dioxide between terrestrial ecosystems and the atmosphere.

\subsection{Input Data}

[12] We developed three types of driving data sets for running the models: (1) data having temporal change, but no spatial variability (atmospheric $\mathrm{CO}_{2}$ concentration); (2) data having spatial variability, but no temporal change (elevation, soil depth, soil pH, and soil texture [Tian et al., 2009]); and (3) data having both temporal and spatial changes (air 
Table 1. Design of the Simulation Experiments

\begin{tabular}{|c|c|c|c|c|c|c|c|}
\hline Experiment & $\mathrm{CO}_{2}$ & Climate & Ozone & N Deposition & N Fertilizer Application & LCLUC & Scenario \\
\hline 1 & $1901-2005$ & $1901-2005$ & $1901-2005$ & $1901-2005$ & $1901-2005$ & $1901-2005$ & Combined \\
\hline 2 & 1900 & $1901-2005$ & $1901-2005$ & $1901-2005$ & $1901-2005$ & $1901-2005$ & Combined without $\mathrm{CO}_{2}$ \\
\hline 3 & $1901-2005$ & Mean & $1901-2005$ & $1901-2005$ & $1901-2005$ & $1901-2005$ & Combined without climate \\
\hline 4 & $1901-2005$ & $1901-2005$ & 1900 & $1901-2005$ & $1901-2005$ & $1901-2005$ & Combined without ozone \\
\hline 5 & $1901-2005$ & $1901-2005$ & $1901-2005$ & 1900 & $1901-2005$ & $1901-2005$ & Combined without $\mathrm{N}$ deposition \\
\hline 6 & $1901-2005$ & $1901-2005$ & $1901-2005$ & $1901-2005$ & $1900-2005$ & 1900 & Combined without LCLUC \\
\hline 7 & $1901-2005$ & $1901-2005$ & $1901-2005$ & $1901-2005$ & 1900 & $1901-2005$ & Combined without $\mathrm{N}$ fertilizer application \\
\hline 8 & $1901-2005$ & mean & 1900 & 1900 & 1900 & 1900 & $\mathrm{CO}_{2}$ only \\
\hline 9 & 1900 & $1901-2005$ & 1900 & 1900 & 1900 & 1900 & Climate only \\
\hline 10 & 1900 & mean & $1901-2005$ & 1900 & 1900 & 1900 & ozone only \\
\hline 11 & 1900 & mean & 1900 & $1901-2005$ & 1900 & 1900 & $\mathrm{~N}$ deposition only \\
\hline 12 & 1900 & mean & 1900 & 1900 & $1901-2005$ & 1900 & $\mathrm{~N}$ fertilizer application only \\
\hline 13 & 1900 & mean & 1900 & 1900 & 1900 & $1901-2005$ & LCLUC only \\
\hline 14 & $1901-2005$ & mean & 1900 & $1901-2005$ & 1900 & 1900 & $\mathrm{CO}_{2}$ and $\mathrm{N}$ deposition \\
\hline
\end{tabular}

temperatures, precipitation, relative humidity, cloudiness [Chen et al., 2006], AOT40 ozone index [Felzer et al., 2005; Ren et al., 2007b], atmospheric nitrogen deposition [Lu and Tian, 2007], land cover and land use type [Liu et al., 2005a, 2005b; Liu and Tian, 2010], and crop management [Ren et al., 2011]). The Accumulated Ozone exposure over a Threshold of 40 parts per billion (AOT40) index is a measure of ozone damage based on the accumulated hourly exposure to ozone concentrations greater than an assumed no-damage threshold of $40 \mathrm{ppb}$ [Fuhrer et al., 1997]. The land cover and land use data set tracks the transitions among natural vegetation, cropland and built-up land covers, whereas the crop management data set tracks changes in annual fertilizer application rates, and prescribes the distribution of irrigated area and various crop rotations and phenologies.

[13] Time series data sets were developed from 1901 to 2005 using several time steps. The climate data (maximum air temperature, minimum air temperature, average air temperature, total precipitation, relative humidity, and cloudiness) and the AOT40 index data were organized at a daily time step, while the atmospheric $\mathrm{CO}_{2}$ concentration, atmospheric nitrogen deposition, and land cover and land use change data sets were developed at an annual time step. As TEM uses monthly climate inputs, the daily data were also aggregated to a monthly time step for TEM. All geographically referenced data sets were organized at a spatial resolution of $10 \mathrm{~km} \times 10 \mathrm{~km}$ with a total of 96,415 grid cells representing China. Further details about these input data sets are provided in Text $\mathrm{S} 1$.

\subsection{Model Simulation}

[14] To better understand the mechanisms controlling carbon storage in the terrestrial ecosystems, we conducted fourteen simulations to examine the effects of six environmental factors: climate, atmospheric $\mathrm{CO}_{2}$, ozone pollution, atmospheric nitrogen deposition, land use change in the absence of fertilizer applications, and the application of nitrogen fertilizers (Table 1). In our study, the climate effects included the influences of both short-term climate variability and longer-term climate change on terrestrial carbon balance. Land use change effects included the influences of (1) land use induced land cover changes associated with cropland establishment and abandonment, and urbanization along with the deforestation, afforestation and reforestation related to these land cover changes; and (2) crop management practices associated with crop rotations and irrigation. The application of nitrogen fertilizers was considered separately from the other crop management practices in our study to allow comparisons of the relative importance of this nitrogen input to terrestrial ecosystems relative to nitrogen inputs by atmospheric deposition.

[15] In each simulation, we determined the initial conditions for every grid cell by first running the two models to equilibrium using the long-term average climate and the 1900 values of all other environmental factors; and then repeatedly running the models using the 30 year detrended climate data and the 1900 values of all other environmental factors until a dynamic equilibrium (i.e., 10 year average NECB $=0.0$ ) was reached. While land use changes were known to occur in China before 1900 [Liu and Tian, 2010], the rate of these changes were not as dramatic before 1900 as afterward. In addition, relatively small changes in the other environmental factors occurred before 1900 so that legacy effects of environmental conditions before 1900 are thought to be small.

[16] After initialization, we applied the time series data of historical land use, climate, $\mathrm{CO}_{2}$, AOT40, atmospheric nitrogen deposition, and nitrogen fertilizer application to the two models to simulate carbon and nitrogen dynamics from 1901 to 2005 . We then determined changes in carbon storage in each simulation by summing the model estimates of annual NECB over the time period of interest (e.g., 19612005, 1980-1989, and 1990-1999). With this approach, our NECB estimates capture both the contemporary effects and the legacy effects of environmental factors. Our analysis focuses on the carbon dynamics between 1961 to 2005 because dramatic changes were occurring in the six environmental factors as documented by a more extensive monitoring network during this time period than was available earlier during the 20 th century.

[17] To determine the relative importance of the six environmental factors on terrestrial carbon storage in China, we used the following protocol. In the combined simulation (experiment 1 in Table 1), we allowed all environmental factors to vary over the study period to determine the overall effects. In the following six simulations (experiment 2 to 7 in Table 1), we held one of the driving environmental factors 
Table 2. Comparison of Model and Eddy Covariance Net Ecosystem Exchange Estimates

\begin{tabular}{|c|c|c|c|c|c|}
\hline Ecosystems/Location & Time Period & $\begin{array}{l}\text { DLEM-Based } \\
\text { Estimate }^{\mathrm{a}}\end{array}$ & $\begin{array}{l}\text { TEM-Based } \\
\text { Estimate }^{\mathrm{a}}\end{array}$ & $\begin{array}{l}\text { Field-Based } \\
\text { Estimate }^{\mathrm{a}}\end{array}$ & References \\
\hline $\begin{array}{l}\text { Temperate mixed forest/Changbaishan } \\
\left(42^{\circ} 24^{\prime} \mathrm{N}, 128^{\circ} 06^{\prime} \mathrm{E}\right)\end{array}$ & 2003 & $-152 \mathrm{~g} \mathrm{C} \mathrm{m}^{-2} \mathrm{yr}^{-1}$ & $-198 \mathrm{~g} \mathrm{C} \mathrm{m}^{-2} \mathrm{yr}^{-1}$ & $-188 \mathrm{~g} \mathrm{C} \mathrm{m}^{-2} \mathrm{yr}^{-1}$ & $W u[2006]$ \\
\hline $\begin{array}{l}\text { Conifer plantation/Qianyanzhou } \\
\left(26^{\circ} 45^{\prime} \mathrm{N}, 115^{\circ} 04^{\prime} \mathrm{E}\right)\end{array}$ & $2003-2004$ & $-426 \mathrm{~g} \mathrm{C} \mathrm{m}^{-2} \mathrm{yr}^{-1}$ & $-496 \mathrm{~g} \mathrm{C} \mathrm{m}^{-2} \mathrm{yr}^{-1}$ & $-424 \mathrm{~g} \mathrm{C} \mathrm{m}^{-2} \mathrm{yr}^{-1}$ & Liu et al. [2006] \\
\hline $\begin{array}{l}\text { Subtropical evergreen broadleaf forest/Dinghushan } \\
\left(23^{\circ} 10^{\prime} \mathrm{N}, 112^{\circ} 32^{\prime} \mathrm{E}\right)\end{array}$ & 2005 & $-332 \mathrm{~g} \mathrm{C} \mathrm{m}^{-2} \mathrm{yr}^{-1}$ & $-348 \mathrm{~g} \mathrm{C} \mathrm{m}^{-2} \mathrm{yr}^{-1}$ & $-436 \mathrm{~g} \mathrm{C} \mathrm{m}^{-2} \mathrm{yr}^{-1}$ & Zhang [2006] \\
\hline Alpine steppe-meadow/Lasha $\left(37^{\circ} 40^{\prime} \mathrm{N}, 91^{\circ} 05^{\prime} \mathrm{E}\right)$ & 2004 & $-9 \mathrm{~g} \mathrm{C} \mathrm{m}^{-2} \mathrm{yr}^{-1}$ & $-6 \mathrm{~g} \mathrm{C} \mathrm{m}^{-2} \mathrm{yr}^{-1}$ & $-6 \mathrm{~g} \mathrm{C} \mathrm{m}^{-2} \mathrm{yr}^{-1}$ & $X u[2006]$ \\
\hline $\begin{array}{l}\text { Alpine tundra/Changbaishan } \\
\left(41^{\circ} 53^{\prime} \text { to } 42^{\circ} 04^{\prime} \mathrm{N}, 127^{\circ} 57^{\prime} \text { to } 128^{\circ} 11^{\prime} \mathrm{E}\right)\end{array}$ & 1998-1999 & $47 \mathrm{~g} \mathrm{C} \mathrm{m}^{-2} \mathrm{yr}^{-1}$ & $39 \mathrm{~g} \mathrm{C} \mathrm{m}^{-2} \mathrm{yr}^{-1}$ & $40 \mathrm{~g} \mathrm{C} \mathrm{m}^{-2} \mathrm{yr}^{-1}$ & Dai et al. [2002] \\
\hline $\begin{array}{l}\text { Winter wheat and summer corn/Yucheng } \\
\left(116^{\circ} 36^{\prime} \mathrm{E}, 36^{\circ} 57^{\prime} \mathrm{N}\right)\end{array}$ & $\begin{array}{l}15 \text { October } 2002 \\
\text { to } 14 \text { October } 2003\end{array}$ & $-193 \mathrm{~g} \mathrm{C} \mathrm{m}^{-2} \mathrm{yr}^{-1}$ & - & $-198 \mathrm{~g} \mathrm{C} \mathrm{m}^{-2} \mathrm{yr}^{-1}$ & Li et al. [2006] \\
\hline
\end{tabular}

${ }^{a} \mathrm{~A}$ negative value represents a terrestrial carbon sink whereas a positive value represents a carbon source.

constant at an initial level, while allowing the rest to change over time. We then quantified the effects of a certain environmental factor on terrestrial carbon storage by calculating the difference in land carbon storage between the experiment where all factors changed over time and the experiment where the factor of interest was held constant. With this approach we captured both the direct effects of an environmental factor on terrestrial carbon sequestration plus interactive effects of this factor with other environmental factors. To examine the relative importance of interactive effects versus direct effects, we conducted another six simulations (experiments $8-13$ in Table 1) where we allowed a particular environmental factor to change over time, while holding the other environmental factors constant at the initial level. In addition, we conducted a simulation (experiment 14 in Table 1) in which $\mathrm{CO}_{2}$ and nitrogen deposition were allowed to vary, but other environmental factors remained constant to help determine interactive effects between these two factors.

[18] While both TEM and DLEM can simulate the changes in vegetation and soil carbon in natural and intensively managed ecosystems, the representation and formulation of ecosystem processes that control carbon source and sink behaviors, however, are different between TEM and DLEM. Because DLEM simulates agricultural systems by crop type while TEM does not, we identified those grid cells dominated by agricultural land (about $15 \%$ of China) and used DLEM-simulated results to estimate carbon balance in these grid cells for both models. Agricultural land plays an important role in determining regional carbon balance, contributing $16 \%$ to net carbon sink of China's terrestrial ecosystems as simulated by TEM and $19 \%$ by DLEM in this study. Our simulations for agricultural land include two components: conversion of natural systems to cropland and the carbon dynamics associated with crop growth. We use the estimate from each of our models to represent the first component whereas only DLEM is involved into calculation of the second one. This two-step simulation gives rise to small difference in carbon flux estimates from TEM and DLEM. The most dramatic divergence is found in northeast China where TEM simulates a small sink and DLEM simulates a small source (Figure S13 in Text S1).

[19] To explore the effects of forest fires on carbon storage in China, we used an off-line fire module with the results of experiment 1. The off-line fire module [Lü et al., 2006] considers the spatial variability in fire-related parameters (e.g., combustion efficiency, emission factors) and fire-scar properties such as vegetation types and biomass, and the carbon accumulation associated with postfire plant regrowth.

\subsection{Model Validation}

[20] Consistency between model results and field measurements is essential for establishing the credibility of biogeochemistry models such as TEM and DLEM. To evaluate model capabilities, we compared our model estimates of net ecosystem production (NEP) to short-term measurements of net ecosystem exchange (NEE) at six eddy covariance sites in China (Table 2). The eddy covariance technique has been recognized as one of the most reliable approaches for estimating the net exchange of carbon dioxide between land ecosystems and the atmosphere. We ran our models in site-specific mode, using the driving variables specific to the grid cell in which the field study was conducted. The model results were in reasonable agreement with the measurements for all sites, with the modeled annual NEE estimates falling within $+/-20$ percent of the eddy flux measurements (Table 2). In addition, the NEP estimated by both TEM and DLEM also captured the daily/seasonal variations in the field NEE estimates at eddy covariance sites in which daily NEE measurements and climate data were available (see Figure S7 in Text S1). Additional model validation can be found in Text S1.

\section{Results}

\subsection{Environmental Changes in China During 1961-2005}

[21] During 1961-2005, the environmental factors controlling terrestrial carbon storage changed substantially across China (Table 3). At the national scale, air temperature, precipitation, atmospheric $\mathrm{CO}_{2}$ concentration, AOT40, nitrogen deposition and the application of nitrogen fertilizers all increased over this time period. The change rate in air temperature $\left(0.29^{\circ} \mathrm{C}\right.$ per decade) was significantly higher than the corresponding global average level during the same time period (about $0.1^{\circ} \mathrm{C}$ increase per decade from 1961 to 2005 [Trenberth et al., 2007]). In addition, we found that the annual mean minimum air temperature increased faster than the annual mean maximum temperature. The faster pace of 
Table 3. Changes of Driving Forces During 1961-2005

\begin{tabular}{|c|c|c|c|c|c|c|}
\hline & Northwest & Middle North & Northeast & Southwest & Southeast & National \\
\hline \multicolumn{7}{|c|}{ Changing Rates Over 45 Years } \\
\hline Tavg $\left({ }^{\circ} \mathrm{C}(10 \mathrm{a})^{-1}\right)$ & $0.30 \pm 0.04 * * *$ & $0.32 \pm 0.05 * * *$ & $0.37 \pm 0.06^{* * *}$ & $0.27 \pm 0.03^{* * *}$ & $0.21 \pm 0.04 * * *$ & $0.29 \pm 0.03 * * *$ \\
\hline $\operatorname{Tmax}\left({ }^{\circ} \mathrm{C}(10 \mathrm{a})^{-1}\right)$ & $0.21 \pm 0.05 * * *$ & $0.24 \pm 0.06^{* * *}$ & $0.26 \pm 0.07^{* * *}$ & $0.25 \pm 0.04 * * *$ & $0.17 \pm 0.05^{* * *}$ & $0.23 \pm 0.04 * * *$ \\
\hline $\operatorname{Tmin}\left({ }^{\circ} \mathrm{C}(10 \mathrm{a})^{-1}\right)$ & $0.42 \pm 0.04 * * *$ & $0.43 \pm 0.05^{* * *}$ & $0.53 \pm 0.06^{* * *}$ & $0.32 \pm 0.03^{* * *}$ & $0.24 \pm 0.04 * * *$ & $0.38 \pm 0.03^{* * *}$ \\
\hline PPT $\left(\mathrm{mm}(10 a)^{-1}\right)$ & $11.20 \pm 3.23^{* * *}$ & $-4.40 \pm 8.02$ & $1.25 \pm 6.98$ & $8.30 \pm 5.58$ & $28.04=16.31^{*}$ & $9.68 \pm 4.06^{* *}$ \\
\hline $\mathrm{CO}_{2}\left(\mathrm{ppm} \mathrm{yr}^{-1}\right)$ & $1.43 \pm 0.02 * * *$ & $1.43 \pm 0.02 * * *$ & $1.43=0.02 * * *$ & $1.43 \pm 0.02 * * *$ & $1.43 \pm 0.02 * * *$ & $1.43=0.02 * * *$ \\
\hline $\begin{array}{l}\text { Nitrogen deposition } \\
\quad\left(\mathrm{mg} \mathrm{N} \mathrm{m} \mathrm{m}^{-2} \mathrm{a}^{-2}\right)\end{array}$ & $6.21 \pm 0.34 * * *$ & $18.91 \pm 0.77 * * *$ & $14.72 \pm 0.57 * * *$ & $15.95 \pm 0.77^{* * *}$ & $42.81 \pm 1.24 * * *$ & $16.72 \pm 0.42 * * *$ \\
\hline $\begin{array}{l}\text { Ozone (mean monthly } \\
\text { AOT40: } \mathrm{ppb} \mathrm{hr}^{-1} \mathrm{yr}^{-1} \text { ) }\end{array}$ & $95.40 \pm 4.45^{* * * *}$ & $82.16 \pm 3.93 * * *$ & $56.25 \pm 3.48 * * *$ & $72.60 \pm 3.01 * * *$ & $38.20 \pm 3.50 * * *$ & $72.49 \pm 3.06 * * *$ \\
\hline $\begin{array}{l}\text { Nitrogen fertilizer } \\
\quad\left(\mathrm{kg} \mathrm{N}^{-1} \mathrm{yr}^{-2}\right)\end{array}$ & $3.88 \pm 0.15 * * *$ & $7.40 \pm 0.23^{* * *}$ & $3.81=0.11 * * *$ & $4.47 \pm 0.12 * * *$ & $7.20=0.18 * * *$ & $5.66 \pm 0.14 * * *$ \\
\hline \multicolumn{7}{|c|}{ Accumulated Changes Over 45 Years } \\
\hline Forest (million ha) & 1.21 & 3.75 & 6.95 & 8.53 & 14.28 & 34.71 \\
\hline Grassland (million ha) & 1.21 & 1.35 & -2.88 & -0.04 & 0.06 & -0.30 \\
\hline Cropland (million ha) & -2.16 & -6.65 & 3.59 & 0.44 & -6.81 & -11.59 \\
\hline Built-up area (million ha) & 0.7 & 3.51 & 1.24 & 0.37 & 3.47 & 9.29 \\
\hline Others (million ha) ${ }^{\mathrm{b}}$ & -0.96 & -1.96 & -8.9 & -9.3 & -11.0 & -32.12 \\
\hline
\end{tabular}

${ }^{\mathrm{a}}$ Positive values, increase; negative values, decrease; ***, $\mathrm{P}<0.01 ; * *, \mathrm{P}<0.05 ; *, \mathrm{P}<0.1$ ).

bothers include tundra, wetland, shrubland, woodland and desert.

increasing minimum temperatures contributed more to the increase of annual mean air temperature than maximum temperature did, which might further imply that the plant growing seasons in China will be lengthened due to either earlier leaf-on time or delayed leaf-off time. The increase in AOT40 over this time period indicated over a 16-fold increase in the exposure of terrestrial ecosystems in China to damaging ozone concentrations. The changes in nitrogen deposition indicated that these atmospheric inputs of nitrogen to terrestrial ecosystems increased $63 \%$ over this time period. The land area covered by forests and built-up areas increased over this time period to replace lands covered by cropland, grassland and other natural vegetation (Table 3 ).

[22] The changes in environmental factors were not uniform across China (Table 3). The largest increases in precipitation, atmospheric nitrogen deposition, and forest area occurred in southeast China; the largest increases in air temperature occurred in northeast China; the largest increases in AOT40 occurred in northwest China; and the largest increases in the application of nitrogen fertilizers and builtup area occurred in middle north China. In contrast, precipitation decreased in the middle north China; cropland area decreased in northwest China, middle north China and southeast China with the largest decreases in southeast China; and grassland area decreased in southwest China and northeast China with the largest decreases in northeast China. These differences suggest that the relative importance of environmental factors on carbon balance may vary across regions in China.

\subsection{National Terrestrial Carbon Balance and the Underlying Mechanisms}

[23] Our simulations indicated that between 1961 and 2005 , changes in six environmental factors (climate, atmospheric $\mathrm{CO}_{2}$, ozone pollution, nitrogen deposition, nitrogen fertilizer application, and land cover and land use change) caused a mean net land carbon sink (NECB) in China of $0.21 \mathrm{Pg} \mathrm{C}$ per year $(0.18 \pm 0.1$ and $0.24 \pm 0.16 \mathrm{Pg} \mathrm{C}$ per year as estimated by DLEM and TEM, respectively), with sub- stantial interdecadal variability (Figure 1). A comparison of the model estimates for NECB and NCE indicated that the influence of these environmental factors on carbon balance was dominated by their effects on the net exchange of carbon dioxide between land and the atmosphere. Both TEM and DLEM track NCE estimates that are slightly larger than their NECB estimates. For TEM, the NCE estimate is $0.26 \mathrm{Pg} \mathrm{C}$ per year including DOC leaching loss while it is $0.19 \mathrm{Pg} \mathrm{C}$ per year from DLEM as a result of including $\mathrm{CH}_{4}$ emissions from the land.

[24] Our model simulations show that, among the six environmental factors affecting carbon storage at the national level, the combination of nitrogen deposition on all ecosystems and nitrogen fertilizer application on crops accounted for $61 \%$ of the net carbon increase (Figure 1). Carbon dioxide fertilization accounted for an additional $33 \%$ of the net increase, and land cover and land use changes for $17 \%$. For the period 1961-2005, both ozone pollution and climate effects reduced the size of the land carbon sink in China. The ozone-pollution reduction was equivalent to $7 \%$ of the net carbon sink, and the reduction associated with climate effects was equivalent to $4 \%$. These effects include both the direct influence of the environmental factor of interest on carbon balance plus the influence of any interactions of this factor with other environmental factors as determined from comparisons of the results from experiments 1 through 7 (Table 1). Our simulations found that the effects of forest fires on carbon storage were negligible in China, averaging to $-0.0039 \mathrm{Pg} \mathrm{C} \mathrm{yr}^{-1}$. Fire-related carbon emissions were largely offset by postfire plant regrowth.

[25] Nitrogen also had an indirect effect on carbon storage by enabling plants to be more responsive to increasing atmospheric $\mathrm{CO}_{2}$. According to our analyses, increased nitrogen deposition enhanced the $\mathrm{CO}_{2}$ fertilization effect on carbon storage by about $70 \%$ in all forests across China, and by about $100 \%$ in the forests in the southeastern China. This nitrogen-enhanced $\mathrm{CO}_{2}$ fertilization effect has been observed in field studies conducted in temperate forest and grassland sites outside of China [Finzi et al., 2007; Reich 


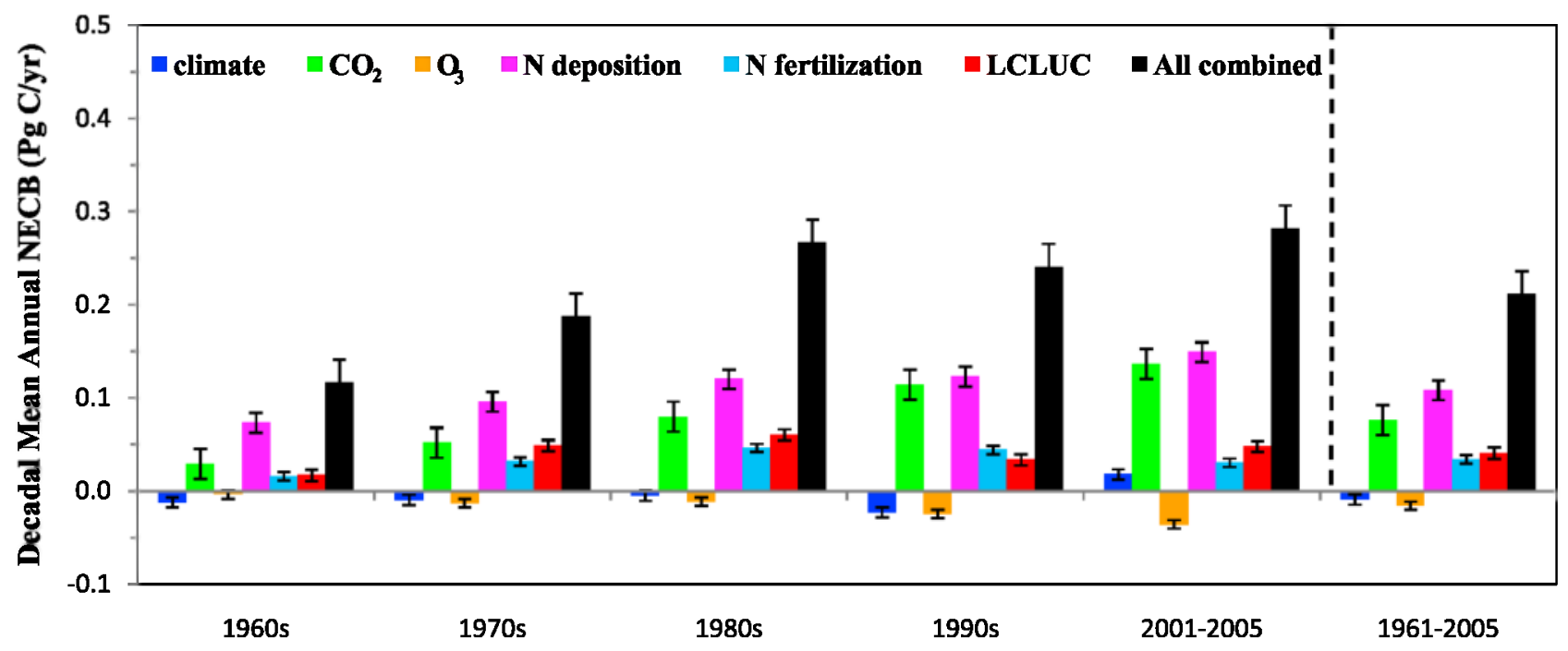

Figure 1. Relative importance of environmental factors on net carbon storage/loss in China from 1961 to 2005. Factors include climate, atmospheric $\mathrm{CO}_{2}$, ozone pollution, nitrogen deposition, $\mathrm{N}$ fertilizer application, and land cover and land use change (LCLUC). Decadal mean annual net ecosystem carbon balance (NECB) is the average calculated from both TEM and DLEM. The standard deviations are calculated from the interannual variability of NECB as simulated by the two models in every decade.

et al., 2006]. Hungate et al. [2003] argued that the models that do not consider the coupling of carbon and nitrogen cycles would overestimate the carbon sequestration caused by enhanced $\mathrm{CO}_{2}$ concentration. Our model simulations however, also indicate that nitrogen stimulation of the $\mathrm{CO}_{2}$ fertilization effect increased over time, enhancing carbon sequestration at the national scale by $30 \%$ in the 1960 s to nearly $100 \%$ during the last 5 years of the study period. Additional interactions among the six environmental factors are described in Text S1.

[26] To determine if previous environmental conditions were influencing the terrestrial carbon dynamics between 1961 and 2005, we compared the estimated carbon stored in vegetation and soil organic matter at the end of 1960 among experiments 1 through 7 . For most environmental factors, we found small differences in vegetation and soil organic carbon stocks from that estimated in the experiment 1 simulation where all environmental factors varied over the 20 th century indicating that these factors had little legacy effects. The one notable exception was the experiment 6 simulation where LCLUC was held constant throughout the 20 th century. A comparison of this simulation with the experiment 1 simulation indicated that land cover and land use changes that occurred in the first half of the century had caused total C stocks in 1960 to decrease by $2.7 \%$ as estimated by DLEM and by $4.1 \%$ as estimated by TEM. The LCLUC impacts were larger on vegetation carbon than on soil organic carbon; both models estimated a $10 \%$ decrease in vegetation carbon by 1960 , but smaller decreases $(0.8 \%$ in DLEM, $1.5 \%$ in TEM) in soil organic carbon stocks. Because the size of the vegetation and soil organic carbon pools influences the ability of the ecosystem to take up and release carbon [Tian et al., 2003; Sokolov et al., 2008], these differences in carbon stocks indicated that contemporary carbon dynamics were indeed being influenced by legacy effects of previous land use change.
[27] The effects and relative importance of each environmental factor on carbon balance as simulated by DLEM and TEM also substantially varied from decade to decade (Figure 1). Throughout the study period (1961 to 2005), elevated $\mathrm{CO}_{2}$ concentration and $\mathrm{N}$ deposition resulted in sustained carbon gains, whereas ozone pollution resulted in sustained carbon losses. None of the other driving forces provided monotonic responses to decadal average NECB during 1961-2005. Warmer and wetter weather during the most recent 5 years resulted in a carbon sink, instead of a source over entire China. The positive role of nitrogen fertilizer application to NECB reached a peak in the 1980 s even though the application rate kept increasing from 1961 to 2005. In contrast to the first part of the 20th century, LCLUC effects generally increased carbon storage between 1961 and 2005. However, temporal variations in large-scale reforestation/afforestation projects occurring since the late 1970 s caused the benefits of the LCLUC effect to fluctuate over this time period. In addition, the expansion of croplands during the 1990s and large-scale cropland abandonment in response to the recently implemented "Grain-for-Green" policy, which is a strategy designed to shift low-yield farmland to forest [Liu et al., 2005a, 2005b; Liu and Tian, 2010], also contribute to the fluctuations in the LCLUC effect over this time period. As a result, the decline of carbon uptake rate in the 1990 s can be attributed to the relatively higher negative impact of climate changes and ozone pollution along with a reduced positive contribution of LCLUC during this decade.

[28] Although interactions between nitrogen deposition and $\mathrm{CO}_{2}$ fertilization appeared to have larger effects on carbon storage during the latter period of the 20th century, the simulated relative contribution of nitrogen deposition overall on carbon balance began to diminish since the $1980 \mathrm{~s}$ (Figure 1) even though the atmospheric nitrogen deposition rate continued to increase as a result of elevated anthropogenic nitrogen input related to fossil fuel combustion, 

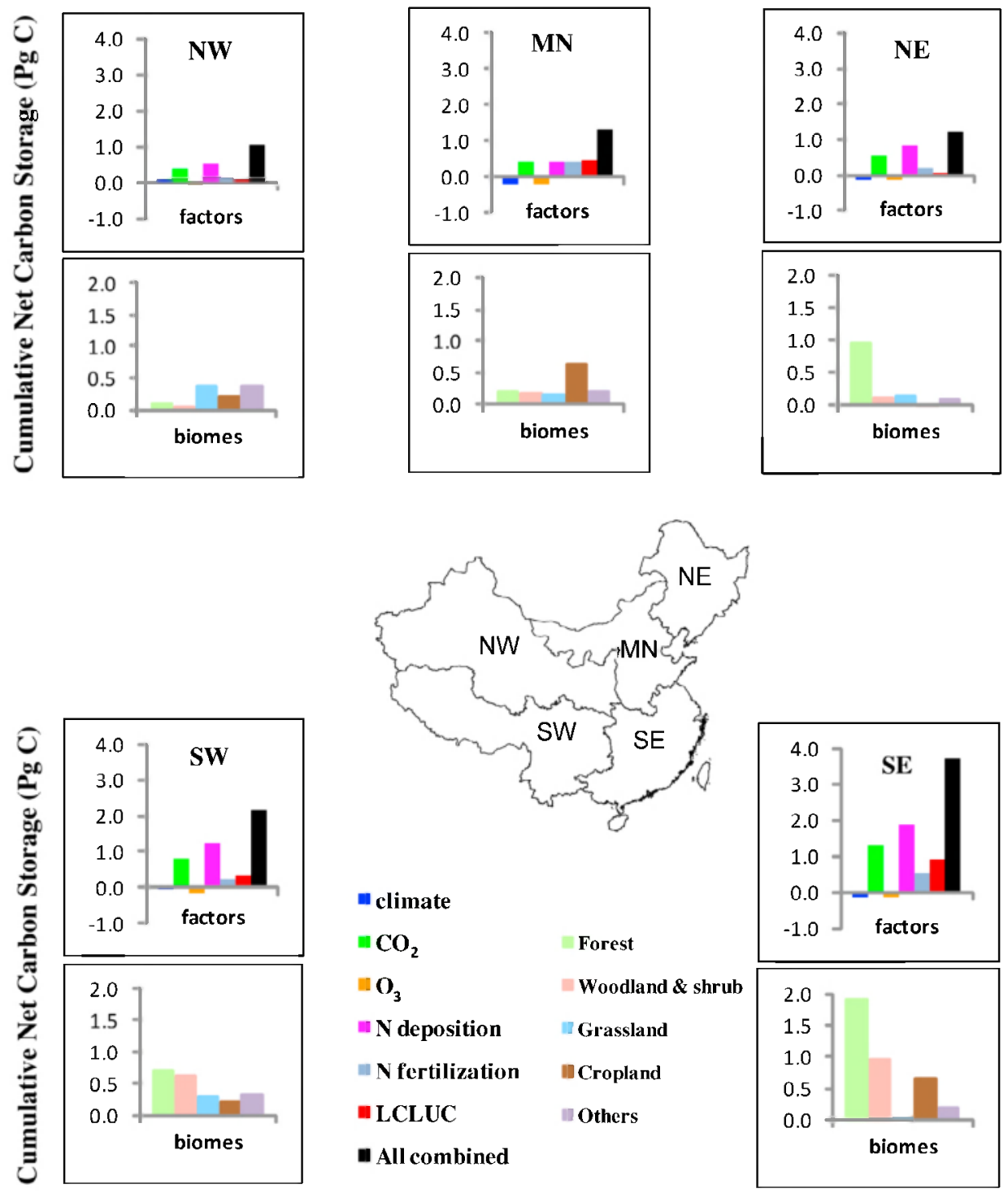

Figure 2. Relative importance of environmental factors and biomes on cumulative net carbon storage (Pg C) of regions within China from 1961 to 2005. Factors include climate, atmospheric $\mathrm{CO}_{2}$, ozone pollution, nitrogen deposition, $\mathrm{N}$ fertilizer application, and land cover and land use change (LCLUC). Biomes include forests, woodland and shrub, grass, crop, and others. Regions include the northwest $(\mathrm{NW})$, middle north (MN), northeast (NE), southwest (SW), and southeast (SE).

fertilizer application and so on. Therefore, the current response rate and magnitude of China's terrestrial ecosystems to chronically enhanced nitrogen inputs appear to be moderate in comparison to those rates of the previous 20 years. This suggests that in recent years, plant productivity is limited by nitrogen availability in fewer areas in China.

\subsection{Role of Major Biomes in the National Carbon Balance}

[29] Our simulations reveal that forest ecosystems were the dominant carbon sinks in China over the study period (Figure 2). DLEM and TEM suggest a carbon sink of $85.3 \mathrm{Tg} \mathrm{C} \mathrm{yr}{ }^{-1}$ or a total of $3.84 \mathrm{Pg} \mathrm{C}$ in forest, with three regions accounting for more than 90 percent of the total: southeast, 49.6 percent; northeast, 24.7 percent; and southwest, 18.2 percent. Forest expansion due to afforestation and reforestation is estimated to contribute about $40 \%$ to the total forest carbon sink, and about $16 \%$ to the total national carbon sink. Other ecosystems functioning as sizable carbon sinks were woodlands and shrublands $\left(42.2 \mathrm{Tg} \mathrm{C} \mathrm{yr}^{-1}\right)$, grasslands (22.0 $\left.\mathrm{Tg} \mathrm{C} \mathrm{yr}^{-1}\right)$, and croplands (36.7 $\mathrm{Tg} \mathrm{C} \mathrm{yr}^{-1}$ ). In many of the cropland areas across China, management practices in recent decades, especially the addition of nitrogen fertilizers, resulted in increases in soil carbon storage. Our simulations indicate that fertilizer applications increased soil carbon storage in croplands by $1.5 \mathrm{Pg} \mathrm{C}$ over the past 45 years.

\subsection{Regional Terrestrial Carbon Balance and the Underlying Mechanisms}

[30] Model simulations suggest that the amount of carbon sequestered and the relative importance of the environ- 
mental factors varied among different regions (Figure 2). In the past 45 years, the estimated highest carbon sequestration occurred in southeast China, accounting for nearly $40 \%$ of national total carbon sink, and the lowest carbon sequestration ( $11 \%$ of national total) occurred in northwest China. In southeast China, most of the carbon was sequestered by forests $(51 \%)$ and influenced mostly by nitrogen deposition $(43 \%), \mathrm{CO}_{2}$ fertilization $(30 \%)$ and LCLUC $(21 \%)$. These general patterns are also found in southwest and northeast China. In contrast, most carbon was sequestered by grasslands (34\% of the regional total) in northwest China and croplands ( $46 \%$ of the regional total) in middle north China. In Text S1, we present a detailed analysis of the mechanisms responsible for carbon sequestration in each region.

\section{Discussion}

[31] Unlike previous studies, our modeling results indicate that nitrogen subsidies to terrestrial ecosystems from nitrogen deposition and the application of nitrogen fertilizers have a major influence on terrestrial carbon sequestration in China. Nitrogen deposition, particularly in southeast China, enhances the availability of nitrogen for uptake by plants to increase primary productivity, which in turn, enhances carbon sink behavior as more carbon is stored in woody vegetation biomass. In addition, the improved nitrogen availability from chronic nitrogen deposition increases the sensitivity of plants to changes in atmospheric $\mathrm{CO}_{2}$ concentration and enhances $\mathrm{CO}_{2}$ fertilization effects on plant primary productivity. Nitrogen deposition also enhances crop primary productivity, but these inputs are dwarfed by the input of 10 to 100 times more nitrogen added to croplands through fertilizer applications (Table 3). The continual harvest of crop biomass, however, limits the potential benefits of these environmental factors on carbon sequestration in agroecosystems such that the influence of other environmental factors become relatively more important on the amount of carbon sequestered in soils.

[32] Our results also suggest that the recent afforestation/ reforestation policies in China have had a significant effect on enhancing carbon sequestration between 1961 and 2005 and compensating for the loss of carbon from LCLUC activities occurring before this time period. These efforts have been assisted by the effects of nitrogen deposition and $\mathrm{CO}_{2}$ fertilization on enhancing forest productivity. Unfortunately, our simulations also suggest that the future benefits of nitrogen deposition on forest productivity may be limited as some areas already appear to be experiencing nitrogen saturation. Future research is needed to further verify the long-term influence of $\mathrm{N}$ deposition on forest carbon uptake.

\subsection{Comparisons to Previous Studies}

[33] Three well-accepted approaches, inventories, atmospheric inversions, and ecosystem models, have been used by other researchers to estimate contemporary carbon budgets in terrestrial ecosystems. For current environmental conditions in China, our modeled estimates of changes in carbon stocks in the vegetation and soil agreed well with the inventory estimates at the biome level and the atmospheric inversion estimates at national level. Our estimates of mean annual carbon sequestration rate and total carbon sink for the period 1981-2000 are comparable to inventory estimates for forests [Pan et al., 2004; Fang et al., 2007] and grasslands [Fang et al., 2007] (Table 4). Our simulated results for carbon storage in cropland soils also fit well with inventory data that report carbon storage rates in the upper $20 \mathrm{~cm}$ of soil. However, we estimate that a total of $0.044{\mathrm{Pg} \mathrm{C} \mathrm{yr}^{-1}}^{-1}$ was actually sequestered in cropland soils down to a depth of $1.5 \mathrm{~m}$ during this time period.

[34] We also compared our estimate of carbon balance against estimates based on two atmospheric inversions; one reported by Piao et al. [2009] and one based on a newly released estimate of global carbon flux at a resolution of $1 \times$ 1 degree from CarbonTracker 2008 [Peters et al., 2007] (http://www.esrl.noaa.gov/gmd/ccgg/carbontracker/index. html). The inversion study by Piao et al. [2009] based its estimates of net terrestrial carbon fluxes on information derived from the ORCHIDEE model, whereas the CarbonTracker study based its estimates on information derived from the CASA model and included the effects of wildfire along with postfire recovery of the ecosystem on these carbon fluxes. For the period 1996-2005, our simulated carbon sink of $0.26 \pm 0.11 \mathrm{Pg} \mathrm{C} \mathrm{yr}^{-1}$ is within the range $\left(0.35 \pm 0.33 \mathrm{Pg} \mathrm{C} \mathrm{yr}^{-1}\right)$ reported by Piao et al. [2009]. Our model estimate of a carbon sink of $0.29 \pm 0.08 \mathrm{Pg} \mathrm{C} \mathrm{yr}^{-1}$ for China also agrees well with the estimate based on CarbonTracker $\left(0.26 \pm 0.09 \mathrm{Pg} \mathrm{C} \mathrm{yr}^{-1}\right)$ for the period 2000-2005.

[35] Given the land carbon sink in the Northern Hemisphere with inversion studies estimating $1.7(0.4$ to 2.3$) \mathrm{Pg}$

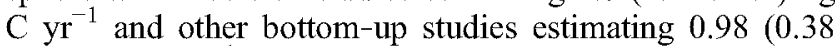
to 1.6) $\mathrm{Pg} \mathrm{C} \mathrm{yr}^{-1}$ [Denman et al., 2007], the modeled carbon

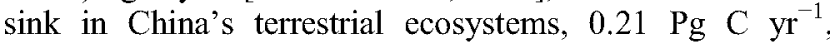
accounts for $12-21 \%$ of carbon sequestration in the Northern Hemisphere. Although inventory and atmospheric inversion approaches provided estimates on the magnitude of terrestrial carbon sink, these two approaches are limited in their ability to attribute the mechanisms that control China's terrestrial carbon sink.

[36] In past studies, the LCLUC effects on carbon balance have been assessed from changes in carbon storage estimated by inventory studies [e.g., Fang et al., 2001] and by bookkeeping models [e.g., Houghton et al., 1983; Houghton, 2002; Houghton and Hackler, 2003] that investigate the carbon release or accumulation in each vegetation, soil and product pool after various land uses. The estimates of carbon flux from LCLUC in China vary from net uptake by the land ecosystems to net releases from them [Fang et al., 2001; $\mathrm{Li}$ and Zhu, 2002; Houghton, 2002; Houghton and Hackler, 2003]. The discrepancy among studies is mainly caused by the different approaches and incomplete accounting of carbon. For example, Fang et al. [2001] suggest a net carbon sink of $0.02 \mathrm{Pg} \mathrm{C} \mathrm{yr}^{-1}$ based on inventoried forest biomass from the late 1970 s to 1998 , which they attribute mainly to forest expansion and regrowth. Houghton and Hackler [2003] find that land use change in China acted as a carbon source, and their estimates on LCLUC-induced carbon source in the $1990 \mathrm{~s}$, however, vary from 0.008 to $0.05 \mathrm{Pg} \mathrm{C} \mathrm{yr}^{-1}$ [Houghton, 2002; Houghton and Hackler, 2003]. Our simulation demonstrates that LCLUC is responsible for a net carbon sink of $0.03 \mathrm{Pg} \mathrm{C} \mathrm{yr}^{-1}$ during the 1990 s with afforestation/reforestation contributing to $0.04 \mathrm{Pg} \mathrm{C} \mathrm{yr}^{-1}$ and land conversions releasing $0.01 \mathrm{Pg} \mathrm{C} \mathrm{yr}^{-1}$. This disagreement occurred for two reasons. First, the input data sets used to 
Table 4. Comparison of Model and Inventory Estimates of Changes in Biomass and Soil Organic Carbon During 1981-2000

\begin{tabular}{|c|c|c|c|c|c|c|}
\hline $\begin{array}{l}\text { Main } \\
\text { Biomes }\end{array}$ & National Scale & Forest & Grassland & $\begin{array}{l}\text { Woodland and } \\
\text { Shrub }\end{array}$ & Cropland & Total \\
\hline \multicolumn{7}{|c|}{ Ecosystem Modeling (This Study) } \\
\hline \multirow[t]{3}{*}{ Biomass } & $\begin{array}{c}\text { Land area } \\
\text { (million } \mathrm{km}^{2} \text { ) }\end{array}$ & $1.26-1.37$ & $3.51-3.53$ & $1.29-1.41$ & $1.4-1.43$ & $7.46-7.74$ \\
\hline & $\begin{array}{c}\text { Biomass } \\
\text { increment } \\
\left(\mathrm{g} \mathrm{C} \mathrm{m}^{-2} \mathrm{yr}^{-1}\right)\end{array}$ & $61.3 \pm 12.7^{\mathrm{a}}$ & $2.7 \pm 5.48$ & $25.4 \pm 8.2$ & & \\
\hline & $\begin{array}{c}\text { Biomass } \\
\text { increment } \\
\left(\mathrm{Pg} \mathrm{C} \mathrm{yr}{ }^{-1}\right)\end{array}$ & $0.082=0.018$ & $0.005 \pm 0.002$ & $0.034 \pm 0.011$ & & $0.121=0.031$ \\
\hline \multirow[t]{2}{*}{$\begin{array}{l}\text { Soil } \\
\qquad(1.5 \mathrm{~m})\end{array}$} & $\begin{array}{c}\text { Soil carbon } \\
\text { sequestration } \\
\left(\mathrm{g} C \mathrm{~m}^{-2} \mathrm{yr}^{-1}\right)\end{array}$ & $12.0 \pm 7.6$ & $6.3 \pm 2.6$ & $9.3 \pm 3.8$ & $28.2=5.5$ & \\
\hline & $\begin{array}{l}\text { Soil carbon } \\
\text { sequestration } \\
\left(\mathrm{PgC} \mathrm{yr}^{-1}\right)\end{array}$ & $0.016 \pm 0.01$ & $0.022 \pm 0.01$ & $0.012 \pm 0.005$ & $\begin{array}{c}0.044 \pm 0.022 \\
(1.5 \mathrm{~m}) \\
0.016 \pm 0.008 \\
(0.2 \mathrm{~m})\end{array}$ & $\begin{array}{c}0.094 \pm 0.047 \\
(1.5 \mathrm{~m})\end{array}$ \\
\hline \multicolumn{7}{|c|}{ Inventory Estimate } \\
\hline \multirow[t]{3}{*}{ Biomass } & $\begin{array}{c}\text { Land area } \\
\left.\text { (million } \mathrm{km}^{2}\right)\end{array}$ & $\begin{array}{c}1.17-1.43{ }^{\mathrm{b}} \\
1.08^{\mathrm{d}}\end{array}$ & $3.34^{\mathrm{b}}$ & $1.78^{\mathrm{b}}$ & $1.18^{\mathrm{c}}$ & $7.37-7.63$ \\
\hline & $\begin{array}{c}\text { Biomass } \\
\text { increment } \\
\left.\left(\mathrm{g} \mathrm{C} \mathrm{m} \mathrm{yr}^{-2}\right)^{-1}\right)\end{array}$ & $\begin{array}{r}57.7,^{\mathrm{b}} \\
62.3^{\mathrm{d}}\end{array}$ & $2.1^{\mathrm{b}}$ & $10.7^{\mathrm{b}}$ & & \\
\hline & $\begin{array}{c}\text { Biomass } \\
\text { increment } \\
\left(\mathrm{Pg} \mathrm{C} \mathrm{yr}{ }^{-1}\right)\end{array}$ & $\begin{array}{c}0.075, b \\
0.068^{\mathrm{d}}\end{array}$ & $0.007^{b}$ & $0.014-0.024^{b}$ & & $0.105 \pm 0.048^{\mathrm{e}}$ \\
\hline \multirow[t]{3}{*}{ Soil } & $\begin{array}{c}\text { Land area } \\
\text { (million } \mathrm{km}^{2} \text { ) }\end{array}$ & $1.30^{\mathrm{e}}(1 \mathrm{~m})$ & $3.31^{\mathrm{e}}(1 \mathrm{~m})$ & $2.15^{\mathrm{e}}(1 \mathrm{~m})$ & $1.20-1.60^{\mathrm{e}}(1 \mathrm{~m})$ & $7.96-8.36$ \\
\hline & $\begin{array}{c}\text { Soil carbon } \\
\text { sequestration } \\
\left(\mathrm{g} C \mathrm{~m}^{-2} \mathrm{yr}^{-1}\right)\end{array}$ & $3.08 \pm 3.08^{\mathrm{e}}$ & $1.81 \pm 0.00^{\mathrm{e}}$ & $18.1 \pm 0.00^{\mathrm{e}}$ & $18.6 \pm 7.8^{\mathrm{e}}$ & \\
\hline & $\begin{array}{l}\text { Soil carbon } \\
\text { sequestration } \\
\left(\mathrm{PgC} \mathrm{yr}^{-1}\right)\end{array}$ & $0.004 \pm 0.004^{\mathrm{e}}$ & $0.006 \pm 0.001^{\mathrm{e}}$ & $0.039 \pm 0.009^{\mathrm{e}}$ & $\begin{array}{c}0.026 \pm 0.011 \\
0.018-0.022^{\mathrm{c}} \\
(0.2 \mathrm{~m})\end{array}$ & $0.075 \pm 0.025^{\mathrm{e}}$ \\
\hline
\end{tabular}

${ }^{a}$ The standard deviation in simulated results is interannual variability of changes in biomass and soil organic carbon during $1981-2000$.

${ }^{\mathrm{b}}$ Inventory data from Fang et al. [2007]. Carbon sequestration rate at national level includes only the four biomes.

${ }^{\mathrm{C}}$ Inventory data from Huang and Sun [2006].

d Inventory data from Pan et al. [2004], estimated during the late 1980s to the early 1990s.

'Inventory data from Piao et al. [2009], estimated during 1980s to $1990 \mathrm{~s}$.

assess the impacts of land use change on carbon dynamics in China portrayed different land use histories. For example, Houghton and Hackler [2003] estimated an increase in forest area of $21 \times 10^{6}$ ha during $1980-2000$, while forest area estimated in this study increased by $12.6 \times 10^{6}$ ha for the same time period [Liu and Tian, 2010]. Our estimate is close to Fang et al.'s [2001] estimate of forest expansion of $10.2 \times$ $10^{6}$ ha during 1977-1998. Also, in our input data, cropland area was shown to decline by $1.6 \times 10^{6}$ ha during $1980-$ 2000 [Liu and Tian, 2010]. However, Houghton and Hackler [2003] reported an opposite trend, with cropland area increasing by $12 \times 10^{6}$ ha for the same time period. The divergent magnitude and distribution of land use patterns lead to substantial differences in the associated estimates of land use effects on carbon sequestration. Second, the difference in estimation approach can partly explain the contrasting results. Bookkeeping models adopt fixed parameters to calculate the carbon dynamic related to regrowth and decay processes in each age class [Houghton and Hackler, 2003]. However, process-based models, such as TEM and DLEM, can simulate the temporal dynamics of the above variables as they are driven by changes in the local climate, $\mathrm{CO}_{2}$ concentration, nitrogen deposition, ozone pollution and land management practices.

[37] In addition to inventories and inverse models, the recently published work of Piao et al. [2009] on the contemporary carbon cycle in China used process-based models to explore the importance of $\mathrm{CO}_{2}$ fertilization and climate on carbon balance in China during the period 1980-2002. They suggest that the land sink of $0.17 \mathrm{Pg} \mathrm{C} \mathrm{yr}^{-1}$ in China during 1980-2002 may be entirely explained by the combined effects of climate and atmospheric $\mathrm{CO}_{2}$ concentrations which are the only two drivers considered in their model. While they did not directly model LCLUC effects, Piao et al. [2009] inferred that land use change effects were either negligible or that regional variations in the land use effects compensated for each other in terms of carbon flux at the country scale. A similar conclusion was drawn by Cao et al. [2003], who argued that climate effects and atmospheric $\mathrm{CO}_{2}$ increase resulted in a net carbon sink of $0.07 \mathrm{Pg} \mathrm{C} \mathrm{yr}^{-1}$ during $1980-2000$, accounting for 44 to $78 \%$ of total terrestrial $\mathrm{C}$ sink in China, given carbon uptake of 
$0.02 \mathrm{Pg} \mathrm{C} \mathrm{yr}^{-1}$ [Fang et al., 2001] to $0.09 \mathrm{Pg} \mathrm{C} \mathrm{yr}^{-1}$ [Li and Zhu, 2002] due to land use change. $M u$ et al. [2008] also estimated a terrestrial carbon sink of $0.16 \mathrm{Pg} \mathrm{C} \mathrm{yr}^{-1}$ caused by $\mathrm{CO}_{2}$ and climate effects in China during 1961-2000. Our study shows different attributions of China's terrestrial net carbon sink from those simulation studies only involving one to three environmental factors.

[38] The DLEM and TEM are part of an emerging family of models that consider the influence of carbon/nitrogen interactions on terrestrial carbon dynamics (e.g., CLM-CN [Thornton et al., 2007]; ISAM [Jain et al., 2009]; LPJ-DyN [Xu-Ri and Prentice, 2008]; LM3V [Gerber et al., 2010]; and $\mathrm{O}-\mathrm{CN}$ [Zaehle and Friend, 2010]). These models predict that less carbon would be sequestered by terrestrial ecosystems than corresponding carbon-only models because carbon uptake in many temperate, boreal and arctic ecosystems is limited by nitrogen availability [Kicklighter et al., 1999; Hungate et al., 2003; Thornton et al., 2007; Bonan, 2008; Sokolov et al., 2008; Zaehle et al., 2010a]. In addition, these models predict that improvements in nitrogen availability will lead to enhancements in plant productivity and carbon sequestration. These improvements in nitrogen availability could occur from warming-induced enhancement of decomposition of soil organic matter [Xiao et al, 1998; Bonan, 2008; Sokolov et al., 2008; Zaehle et al., 2010a; Bonan and Levis, 2010] or by the addition of nitrogen to the ecosystem through the application of nitrogen fertilizer [Felzer et al., 2004, 2005; Zaehle et al., 2010b] or atmospheric nitrogen deposition [Thornton et al., 2007; Jain et al., 2009; McGuire et al., 2010; Zaehle et al., $2010 \mathrm{~b}$ ]. In previous studies, the benefits of atmospheric nitrogen deposition on terrestrial carbon sequestration have been secondary to $\mathrm{CO}_{2}$ fertilization effects. In our study, however, these nitrogen deposition effects have been greater than the corresponding $\mathrm{CO}_{2}$ fertilization effects. This difference in relative response is largely a result of the higher rates of atmospheric nitrogen deposition that are assumed to occur in our study than other studies. As described in Text S1, our estimates of nitrogen deposition are much closer to deposition data acquired from the monitoring network in China than the results of a global atmospheric deposition model [Dentener, 2006], which is normally used by others [Thornton et al., 2007; Jain et al., 2009; Zaehle and Friend, 2010]. A recent study using DLEM only [ $L u, 2009]$ turns out that the estimate of carbon sink induced by $\mathrm{N}$ deposition largely depended on the forcing data sets we used. The carbon uptake driven by nitrogen deposition data from atmospheric transport models [Dentener, 2006] is simulated to be $56 \%$ of that driven by the monitoring-based data in our study (see Text S1 and also $L u$ and Tian [2007]). This difference suggests that improvements in the spatial and temporal representation of atmospheric nitrogen deposition are needed to improve our understanding of terrestrial carbon dynamics.

[39] Furthermore, the previous modeling studies of carbon dynamics in China also did not account for the influence of ozone pollution, and land management practices, such as fertilizer applications, crop rotations and irrigation, on carbon dynamics. Thus, our results suggest that the inference by Piao et al. [2009] of negligible or regionally compensating LCLUC effects in China is incorrect and is most likely a result of $\mathrm{CO}_{2}$ fertilization effects being over- estimated by the models used in that study. We argue that multiple factors ought to be considered in future modeling studies designed to simulate terrestrial carbon dynamics in China.

[40] While we did consider the concurrent effects of more environmental factors on carbon balance than addressed in previous studies, there are a number of additional issues that we did not consider in our study and that could be addressed in future studies to improve our understanding of carbon dynamics in China. For example, we did not consider the effects of potential changes in the distribution of natural vegetation over the last century on carbon balance. Also, we only considered the effects of nitrogen limitation on carbon dynamics and assumed other key nutrients, such as K, P etc., were sufficient and did not limit productivity in our simulations. Furthermore, there are several aspects of land management practices, such as tillage, manure application, forest plantation management, and thinning, as well as nitrogen fertilizer application in managed forests, that were not fully addressed in our simulations due to a lack of historical records. These missing factors introduce some bias in our current estimates, and improved ecosystem model and input data sets are needed to elucidate the uncertainties caused by model simplification in the future studies.

[41] In addition to missing factors, there were some aspects of the land use legacy effects that may need further exploration. While the legacy effects of environmental changes that took place since 1900 are included in our estimates of NECB, we assumed that carbon dynamics in both models were in a dynamic equilibrium in the year of 1900 . This equilibrium assumption implies that there were no legacy effects related to the decomposition of woody debris or product pools from prior land use change on carbon balance at that time, but the simulations still would have captured the legacy effects of a reduced capacity of ecosystems to take up and release carbon based on the reduced stocks of vegetation and soil organic carbon. However, a large area of forest was known to be converted into cropland and woodland between 1700 and 1900 [Liu and Tian, 2010]. This may have led us to overestimate the size of the carbon sink during the 20 th century by neglecting the effects of decomposition of woody debris product pools with long half-lives from deforestation that occurred before 1900 . We believe the magnitude of this overestimation on carbon dynamics between 1961 and 2005 is minimal, but additional studies would be needed to verify this assumption.

\subsection{Importance of Carbon/Nitrogen Interactions on Carbon Balance}

[42] Although many studies have highlighted the critical role of nitrogen deposition to terrestrial carbon sink in Europe, USA and across globe [Townsend et al., 1996; Holland et al., 1997; Churkina et al., 2007; Magnani et al., 2007; Jain et al., 2009], little is known yet about N-induced carbon uptake in China due to lack of data. A recent study [de Vries et al., 2009] indicates an additional carbon sink of 20-75 kg C per $\mathrm{kg} \mathrm{N}$ input for European forests with ranges of $15-40 \mathrm{~kg} \mathrm{C} / \mathrm{kg} \mathrm{N}$ occurred in aboveground carbon accumulation and of $5-35 \mathrm{~kg} \mathrm{C} / \mathrm{kg} \mathrm{N}$ in soil carbon pool. We found that the average $\mathrm{N}$-induced carbon sequestration in China's forest ecosystems varied from 0 to $59 \mathrm{~kg} \mathrm{C} / \mathrm{kg} \mathrm{N}$ as simulated by TEM, and from 0 to $21 \mathrm{~kg} \mathrm{C} / \mathrm{kg} \mathrm{N}$ simulated 


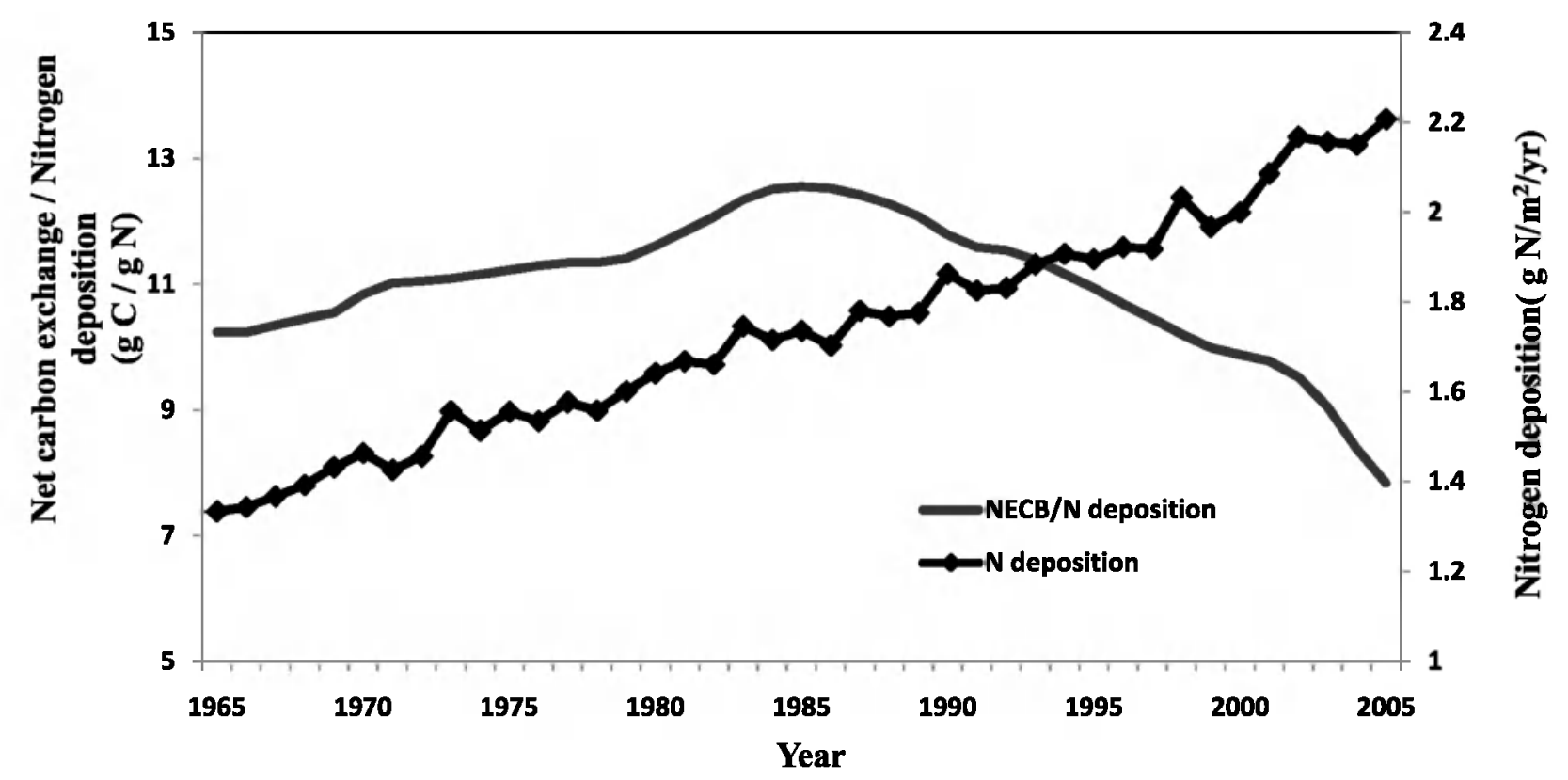

Figure 3. Changes in nitrogen $(\mathrm{N})$ deposition effects on carbon storage in terrestrial ecosystems in China from 1961 to 2005. The ratio of net ecosystem carbon balance (NECB) to nitrogen deposition (solid black line) indicates the amount of carbon sequestered per gram of deposited nitrogen. Before 1985, this ratio increases with time indicating that more carbon is being sequestered per gram of deposited nitrogen as nitrogen deposition increases as a result of interactions with increasing atmospheric $\mathrm{CO}_{2}$ (see section 3.2). After 1985, less carbon is being sequestered per gram of deposited nitrogen even though nitrogen deposition continues to increase because more areas have reached nitrogen saturation.

by DLEM for the 1990s. Therefore, our result is roughly consistent with the values of carbon sequestration per unit nitrogen addition estimated through empirical relationship between carbon uptake and nitrogen gradient, ${ }^{15} \mathrm{~N}$ field experiments, long-term nitrogen fertilizer experiments, as well as ecosystem model simulations [de Vries et al., 2009]. However, the nationwide response ratio found in this study, averaging to $10 \mathrm{~kg} \mathrm{C} / \mathrm{kg} \mathrm{N}$ across China during the $1990 \mathrm{~s}$, is slightly lower than others' work at global scale [Townsend et al., 1996; Holland et al., 1997]. The lower response of carbon sequestration estimated in our study might be associated with negative interactive effects from climate and ozone pollution and the complex responses introduced by land use change and land management, which are neglected by a number of models [Townsend et al., 1996; Holland et al., 1997]. In addition, the fact that our estimate includes large areas of less responsive ecosystems, such as grassland, cropland and desert, is likely partly responsible for the lower response. Besides, our simulation finds that plant productivity in some areas of southeast China is not limited by nitrogen or is N-saturated in recent years (Figure 3). Similar to field studies from heavy nitrogen-deposition areas of Europe and the United States [Fisher et al., 2007], researchers at the Dinghushan Forest Ecosystem Research Station in the southeastern China have documented nitrogen saturation conditions, especially for old-growth forests of the area [Fang et al., 2008]. Under ambient nitrogen deposition levels (29-35 kg N ha ${ }^{-1} \mathrm{yr}^{-1}$ ), they found that no additional nitrogen was retained in these forests, but rather a net loss of $8-16 \mathrm{~kg} \mathrm{~N} \mathrm{ha}^{-1} \mathrm{yr}^{-1}$ was observed and nitrogen fertilizer additions failed to increase plant growth [Fang et al., 2008]. Thus, additional nitrogen input would not stimulate terrestrial carbon uptake any further in these regions, which may also partly account for the lower response induced by nitrogen deposition in this study. During the same period, northwest China is the least responsive region with $\mathrm{N}$-induced carbon sequestration of $5.5 \mathrm{~kg} \mathrm{C} / \mathrm{kg} \mathrm{N}$, which is probably caused by colimitation from water availability and heat supply. Carbon response in other areas ranges from $8 \mathrm{~kg} \mathrm{C} / \mathrm{kg} \mathrm{N}$ in the middle northern China to $17 \mathrm{~kg} \mathrm{C} / \mathrm{kg} \mathrm{N}$ in the northeast China.

[43] The documented crop yield data in China showed that net primary production (NPP) in agriculture land markedly increased from 1950 to 1999 and synthetic fertilizer $(\mathrm{N}, \mathrm{P}, \mathrm{K})$ application is likely responsible for much of this increase [Huang et al., 2007]. Because most crop biomass is removed with harvests, carbon sequestration will mainly occur by the incorporation of crop residue into the soil organic carbon (SOC) pool. Soil survey data also indicated that cropland SOC in China has increased over the recent 2 decades. This increase might be partially caused by fertilized NPP enhancing crop residue inputs to soils [Huang and Sun, 2006; Sun et al., 2009]. However, the inventory data cannot quantify the contribution of synthetic fertilizer to SOC sequestration, nor distinguish the role of nitrogen fertilizer among nutrient combination. A recent study [Lu et al., 2009] compiled 84 paired data sets from 28 agriculture sites in China to investigate the soil carbon sequestration induced by nitrogen fertilizer application. They found that current nitrogen fertilization rate of $12.1 \mathrm{Mt} \mathrm{yr}^{-1}$ in China can 
sequester $0.006 \mathrm{Pg} \mathrm{C}$ each year, which can be raised to $0.012 \mathrm{Pg} \mathrm{C} \mathrm{yr}^{-1}$ with the recommended application of

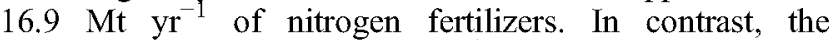
application of $14.7 \mathrm{Mt} \mathrm{N} \mathrm{yr}^{-1}$ of nitrogen fertilizers contributed to a net carbon sink of $0.03 \mathrm{Pg} \mathrm{C} \mathrm{yr}^{-1}$ during 1961-2005 in our study. The relatively higher response compared to $\mathrm{Lu}$ et al. [2009] is partly attributed to the fact that we accounted for carbon sequestration and nitrogen fertilizer applications in all crop types in China in this study whereas they only estimated the carbon sequestration in rice, wheat and maize, covering $46.6 \%$ of China's total cropland area and receiving less than $50 \%$ of the national total nitrogen fertilizer application [Lu et al., 2009]. In addition, they based their analysis on the crop area in each province during 2003 and overlooked the potential effects of land use changes on these estimates of fertilizer-induced carbon sinks. Cropland area decreased by $11.6 \times 10^{6}$ ha during 1961-2005 (Table 3) and this reduction covered nearly $20 \%$ of total cropland area with nitrogen fertilizer application in their study. Thus, by neglecting land use change, Lu et al. [2009] probably underestimated fertilizerinduced soil carbon sequestration.

[44] Recently, more modeling groups simulating global carbon dynamics are beginning to incorporate carbon/ nitrogen interactions into their simulations to improve their representation of carbon dynamics [e.g., Thornton et al., 2007, 2009; Sokolov et al., 2008; Jain et al., 2009; Gerber et al., 2010; Zaehle et al., 2010a]. We expect that in the near future a number of these models will provide new projections of the carbon budget of China that will fully account for carbon nitrogen interactions as TEM and DLEM have done here.

\subsection{Policy Implications of This Study}

[45] Our analysis of the mechanisms controlling carbon storage in China in recent decades has a number of policy implications. Three obvious actions that will enhance carbon storage in China and have other societal benefits are (1) the continued promotion of afforestation and reforestation projects; (2) the reduction of tropospheric ozone; and (3) the use of best practices to manage croplands. Our analyses indicate that the expansion of forest areas due to afforestation and reforestation has already resulted in a large increase of carbon storage in China. The implementation of the "Grain-for-Green" policy will continue to increase carbon storage in forests and grassland, and bring other benefits including protection against soil erosion and the creation of a more biodiversity-rich landscape.

[46] Air pollution, especially tropospheric ozone pollution, is one of most pressing environmental concerns in China today [Fu et al., 2007]. Observations, consistent with our simulation results, have shown that high ozone concentrations have reduced carbon sequestration in China's ecosystems [Chameides et al., 1999; Wang et al., 2007]. Therefore, reductions in tropospheric ozone pollution will help to mitigate climate change by enhancing carbon storage although our analyses suggest the benefits of these reductions on carbon balance may be limited.

[47] In addition to increasing atmospheric ozone concentrations, air pollution contributes to atmospheric nitrogen deposition. Although we have identified nitrogen deposition inputs as a major stimulator of the terrestrial carbon sink during 1961-2005, there are many reports documenting the negative environmental effects of nitrogen deposition in China [Fang et al., 2008; Fu et al., 2007] and across the globe [Galloway et al., 2008]. These negative effects include water pollution, soil acidification, and increased emissions of nitrous oxide, a very powerful greenhouse gas. Environmental policies to regulate the negative effects of nitrogen deposition will also reduce carbon sequestration rates in areas of China where plant growth is nitrogen limited. Hence, to amplify the carbon sink of China's terrestrial ecosystems, the emphasis should be put on increasing nitrogen use efficiency rather than raising nitrogen input amounts in the coming years. Modeling tools, like the ones we have developed, can give policy makers insights into the environmental costs and benefits of aggressively reducing nitrogen deposition on the Chinese landscape.

[48] China's cropland ecosystems have functioned as an important carbon sink in recent decades due to intensive management. "Best farming practices" including water and nutrients management options, can be used to continue to increase carbon storage in agricultural soils, which will also lead to other benefits including increases in fertility and water-storage capacity. The use of inorganic nitrogen fertilizers, however, will have to be better synchronized with crop demands for nitrogen in order to avoid the negative consequences that result when nitrogen supply exceeds plant demand. Ju et al. [2009] have shown that crops are overfertilized in China and the current nitrogen fertilizer application rate could be reduced by 30 to $60 \%$ and maintain crop yields but lower the risk of nitrogen pollution to water and air quality.

\section{Conclusion}

[49] In this study, two process-based ecosystem models, TEM and DLEM are used to investigate the relative importance of changes in climate, atmospheric composition, precipitation chemistry, land use and land management practices on terrestrial carbon balance between China's terrestrial ecosystems and the atmosphere during the period 1961-2005. Our study has identified nitrogen inputs as the primary driver of carbon sequestration in China over the past 45 years, with $\mathrm{CO}_{2}$ fertilization and land use changes also being important mechanisms responsible for carbon storage.

[50] Our findings further suggest that over time the fraction of China's carbon sink attributable to nitrogen inputs will diminish as the magnitude of these inputs is deliberately reduced to address the severe problems of nitrogen-driven air and water pollution faced in the many parts of the country. Chinese policy makers will have to factor this connection between the carbon and nitrogen cycles into any strategy they develop for reducing net $\mathrm{CO}_{2}$ emissions to the atmosphere.

[51] With existing observations from landscape gradients and experimental manipulations, it is challenging to verify the simulated attributions of the net carbon sink in China (or elsewhere) in terms of multiple environment forces and their interactions. In a heterogeneous world involving complicated responses, experimental studies focusing on multifactorial/multitreatment manipulations are needed to better represent the range of conditions that exist today. These 
multifactor studies will provide insights for model development and evaluation, especially for the modeling exploration of natural and anthropogenic attributions to dynamics of terrestrial ecosystems in response to a globally changing environment.

[52] Acknowledgments. This study has been supported by NASA IDS Program (NNG04GM39C), NASA LCLUC Program (NNX08AL73G_S01), and China's Ministry of Science and Technology (MOST) 973 Program (2002CB412500). We thank Maosheng Zhao at the University of Montana for processing the MODIS NPP data, Pieter Tans and his team at NOAA Earth System Science Laboratory for approving us to use the CarbonTracker 2008 results for model evaluation, and three anonymous reviewers for helpful comments on an earlier draft of the manuscript.

\section{References}

Aber, J., et al. (1998), Nitrogen saturation in temperate forest ecosystem, BioScience, 48, 921-934, doi:10.2307/1313296.

Amthor, J. S., et al. (2001), Boreal forest $\mathrm{CO}_{2}$ exchange and evapotranspiration predicted by nine ecosystem process models: Intermodal comparisons and relationships to field measurements, J. Geophys. Res., I06 (D24) 33,623-33,648, doi:10.1029/2000JD900850.

Baldocchi, D. D. (2003), Assessing the eddy covariance technique for evaluating carbon dioxide exchange rates of ecosystems: Past, present and future, Global Change Biol., 9, 479-492.

Balshi, M. S., et al. (2007), The role of historical fire disturbance in the carbon dynamics of the pan-boreal region: A process-based analysis, $J$ Geophys. Res., 112, G02029, doi:10.1029/2006JG000380.

Balshi, M. S., et al. (2009), Vulnerability of carbon storage in North American boreal forests to wildfires during the 21 st century, Global Change Biol, 15, 1491-1510, doi:10.1111/j.1365-2486.2009.01877.x.

Boden, T. A., G. Marland, and R. J. Andres (2009), Global, regional, and national fossil-fuel $\mathrm{CO}_{2}$ emissions, Carbon Dioxide Inf. Anal. Cent., Oak Ridge Natl. Lab., U.S. Dept. of Energy, Oak Ridge, Tenn., doi:10.3334/ CDIAC/00001.

Bonan, G. (2008), Carbon cycle: Fertilizing change, Nat. Geosci., 1, 645-646, doi:10.1038/ngeo328

Bonan, G. B., and S. Levis (2010), Quantifying carbon-nitrogen feedbacks in the Community Land Model (CLM4), Geophys. Res. Lett., 37 , L07401, doi:10.1029/2010GL042430.

Cao, M. K., et al. (2003), Response of terrestrial carbon uptake to climate interannual variability in China, Global Change Biol., 9, 536-546, doi: $10.1046 / \mathrm{j} .1365-2486.2003 .00617 . x$.

Chameides, W. L., et al. (1999), Is ozone pollution affecting crop yields in China?, Geophys. Res. Lett., 26, 867-870, doi:10.1029/1999GL900068.

Chapin, F. S., III, et al. (2006), Reconciling carbon-cycle concepts, terminology, and methods, Ecosystems, 9, 1041-1050, doi:10.1007/s10021005-0105-7.

Chen, G. S., et al. (2006), Climate impacts on China's terrestrial carbon cycle: An assessment with the dynamic land ecosystem model, in Environmental Modeling and Simulation, edited by H. Q. Tian, pp. 56-70, ACTA Press, Calgary, Alb., Canada.

Churkina, G., K. Trusilova, M. Vetter, and F. Dentener (2007), Contribution of nitrogen deposition and forest regrowth to terrestrial carbon uptake, Carbon Balance Manage., doi:10.1186/1750-0680-2-5.

Ciais, P., et al. (2005), Europe-wide reduction in primary productivity caused by heat and drought in 2003, Nature, 437, 529-533, doi:10.1038/ nature03972.

Clein, J. S., et al. (2002), Historical and projected carbon balance of mature black spruce ecosystems across North America: The role of carbonnitrogen interactions, Plant Soil, 242(1), 15-32, doi:10.1023 A: 1019673420225

Cleveland, C. C., et al. (1999), Global patterns of terrestrial biological nitrogen $\left(\mathrm{N}_{2}\right)$ fixation in natural ecosystems, Global Biogeochem. Cycles, 13(2), 623-645, doi:10.1029/1999GB900014.

Compton, J. E., and R. D. Boone (2000), Long-term impacts of agriculture on soil carbon and nitrogen in New England forests, Ecology, 81, 2314-2330, doi:10.1890/0012-9658(2000)081 [2314:LTIOAO]2.0.CO;2.

Dai, L. M., et al. (2002), Carbon cycling of alpine tundra ecosystems on Changbai Mountain and its comparison with arctic tundra, Sci. China, Ser. $D, 45,903-910$, doi: $10.1360 / 02$ yd 9089 . de Vries, W., et al. (2009), The impacts of nitrogen deposition on carbon sequestration by European forest and heathlands, For. Ecol. Manage., 258, 1814-1823, doi:10.1016/j.foreco.2009.02.034.

Denman, K. L. et al. (2007), Couplings between changes in the climate system and biogeochemistry, in Climate Change 2007: The Physical Science Basis. Contribution of Working Group I to the Fourth Assessment Report of the Intergovernmental Panel on Climate Change, edited by S. Solomon et al., pp. 501-587, Cambridge Univ. Press, Cambridge, U. K.

Dentener, F. J. (2006) Global Maps of Atmospheric Nitrogen Deposition, 1860, 1993, and 2050, data set, http://daac.ornl.gov/, Oak Ridge Nat1. Lab. Distrib. Act. Arch. Cent., Oak Ridge, Tenn.

Euskirchen, E. S., et al. (2006), Importance of recent shifts in soil thermal dynamics on growing season length, productivity and carbon sequestration in terrestrial high-latitude ecosystems, Global Change Biol., 12(4), 731-750, doi:10.1111/j.1365-2486.2006.01113.x.

Fang, J. Y., A. P. Chen, C. H. Peng, S. Q. Zhao, and L. Ci (2001), Changes in forest biomass carbon storage in China between 1949 and 1998, Science, 292, 2320-2322, doi:10.1126/science.1058629.

Fang, J. Y., Z. D. Guo, S. L. Piao, and A. P. Chen (2007), Terrestrial vegetation carbon sinks in China, 1981-2000, Sci. China Ser. D, 50 $1341-1350$

Fang, Y. T., P. Gundersen, J. M. Mo, and W. X. Zhu (2008), Input and output of dissolved organic and inorganic nitrogen in subtropical forests of south China under high air pollution, Biogeosciences, 5, 339-352, doi: $10.5194 /$ bg-5-339-2008

Felzer, B., et al. (2004), Effects of ozone on net primary production and carbon sequestration in the conterminous United States using a biogeochemistry model, Tellus, Ser. B, 56, 230-248.

Felzer, B. S., et al. (2005), Future effects of ozone on carbon sequestration and climate change policy using a global biochemistry model, Clim. Change, 73, 345-373, doi:10.1007/s10584-005-6776-4.

Felzer, B. S., T. Cronin, J. M. Reilly, J. M. Melillo, and X. Wang (2007), Impacts of ozone on trees and crops, C. R. Geosci., 339, 784-798, doi:10.1016/j.crte. 2007.08 .008

Finzi, A. C., et al. (2007), Increases in nitrogen uptake rather than nitrogenuse efficiency support higher rates of temperate forest productivity under elevated $\mathrm{CO}_{2}$, Proc. Natl. Acad. Sci. U. S. A., 104, 14,014-14,019, doi:10.1073/pnas.0706518104

Fisher, L. S., P. A. Mays, and C. L. Wylie (2007), An overview of nitrogen critical loads for policy makers, stakeholders, and industries in the United States, Water Air Soil Pollut. , 179, 3-18, doi:10.1007/s11270-006-9235-6. Fu, B. J., X. L. Zhuang, G. B. Jiang, J. B. Shi, and Y. H. Lü (2007), Environmental problems and challenges in China, Environ. Sci. Technol., 41, 7597-7602, doi:10.1021/es0726431.

Fuhrer, J., L. Skärby, and M. R. Ashmore (1997), Critical levels for ozone effects on vegetation in Europe, Environ. Pollut., 97, 91-106, doi:10.1016/S0269-7491(97)00067-5.

Galford, G. L., et al. (2011), Carbon emissions and uptake from 105 years of land-cover and land-use change at the agricultural frontier of the Brazilian Amazon, Ecol. Appl, doi:10.1890/09-1957.1, in press.

Galloway, J. N., et al. (2008), Transformation of the nitrogen cycle: Recent trends, questions, and potential solutions, Science, 320, 889-892, doi:10.1126/science. 1136674

Gerber, S., L. O. Hedin, M. Oppenheimer, S. W. Pacala, and E. Shevliakova (2010), Nitrogen cycling and feedbacks in a global dynamic land model, Global Biogeochem. Cycles, 24, GB1001, doi:10.1029/2008GB003336.

Goodale, C. L., and J. D. Aber (2001), The long-term effects of land-use history on nitrogen cycling in northern hardwood forests, Ecol. Appl., 11, 253-267, doi:10.1890/1051-0761(2001)011[0253:TLTEOL]2.0. $\mathrm{CO} ; 2$

Heimann, M., and M. Reichstein (2008), Terrestrial ecosystem carbon dynamics and climate feedbacks, Nature, 451, 289-292, doi:10.1038/ nature 06591

Holland, E. A., et al. (1997), Variations in the predicted spatial distribution of atmospheric nitrogen deposition and their impact on carbon uptake by terrestrial ecosystems, J. Geophys. Res., 102, 15,849-15,866, doi:10.1029/96JD03164

Houghton, R. A. (2002), Temporal patterns of land-use change and carbon storage in China and tropical Asia, Sci. China Ser. C, 45, 10-17.

Houghton, R. A. (2007), Balancing the global carbon budget, Annu. Rev Earth Planet. Sci., 35, 313-347, doi:10.1146/annurev.earth. 35.031306 .140057

Houghton, R. A., and J. L. Hackler (2003), Sources and sinks of carbon from land-use change in China, Global Biogeochem. Cycles, 17(2), 1034, doi:10.1029/2002GB001970

Houghton, R. A., et al. (1983), Changes in the carbon content of terrestrial biota and soils between 1860 and 1980: A net release of $\mathrm{CO}_{2}$ to the atmosphere, Ecol. Monogr., 53(3), 235-262, doi:10.2307/1942531. 
Huang, Y., and W. J. Sun (2006), Changes in topsoil organic carbon of croplands in mainland China over the last two decades, Chin. Sci. Bull. 51, 1785-1803, doi:10.1007/s1 1434-006-2056-6.

Huang, Y., W. Zhang, W. Sun, and X. Zheng (2007), Net primary production of Chinese croplands from 1950 to 1999 , Ecol. Appl., 17, 692-701, doi: $10.1890 / 05-1792$.

Hungate, B. A., J. S. Dukes, M. R. Shaw, Y. Q. Luo, and C. B. Field (2003), Nitrogen and climate change, Science, 302, 1512-1513.

Jain, A., et al. (2009), Nitrogen attenuation of terrestrial carbon cycle response to global environmental factor, Global Biogeochem. Cycles, 23, GB4028, doi:10.1029/2009GB003519

Ju, X. T., et al. (2009), Reducing environmental risk by improving $\mathrm{N}$ management in intensive Chinese agriculture systems, Proc. Natl. Acad. Sci. U.S.A., doi:10.1073/pnas.0813417106.

Kicklighter, D. W., et al. (1999), A first-order analysis of the potential role of $\mathrm{CO}_{2}$ fertilization to affect the global carbon budget: A comparison study of four terrestrial biosphere models, Tellus, Ser. B, 51, 343-366.

Latty, E. F., C. D. Canham, and P. L. Marks (2004), The effects of land-use history on soil properties and nutrient dynamics in northern hardwood forests of the Adirondack Mountains, Ecosystems, 7, 193-207, doi: $10.1007 / \mathrm{s} 10021-003-0157-5$.

Levine, M. D., and N. T. Aden (2008), Global carbon emissions in the coming decades: The case of China, Annu. Rev. Environ. Resour., 33 , 19-38, doi:10.1146/annurev.environ.33.012507.172124.

Li, J., et al. (2006), Carbon dioxide exchange and the mechanism of environmental control in a farmland ecosystem in North China Plain, Sci China Ser. D, 149, 226-240.

Li, K., and Z. Zhu (2002), Forestation and the changes in forest carbon storage arising from land uses in China, in Changes in Land Use and Cover and Ecosystem Carbon Processes, edited by K. Li, pp. 209-233, Meteorol. Press, Beijing.

Liu, M., and H. Q. Tian (2010), China's land-cover and land-use change from 1700 to 2005: Estimations from high-resolution satellite data and historical archives, Global Biogeochem. Cycles, 24, GB3003 doi: $10.1029 / 2009 \mathrm{~GB} 003687$

Liu, J. Y., et al. (2005a), Current status and recent changes of cropland in China: An analysis based on Landsat TM data, Remote Sens. Environ. 98, 442-456, doi:10.1016/j.rse.2005.08.012.

Liu, J. Y., et al. (2005b), China's changing landscape during the 1990s: Large-scale land transformation estimated with satellite data, Geophys. Res. Lett., 32, L02405, doi:10.1029/2004GL021649.

Liu, M. L., H. Q. Tian, G. S. Chen, C. Zhang, and J. Y. Liu (2008), Effects of land use and land cover change on evapotranspiration and water yield in China during the 20 th century, $J$. Am. Water Resour. Assoc., 44, 1193-1207, doi:10.1111/j.1752-1688.2008.00243.x.

Liu, Y., et al. (2006), Seasonal dynamics of $\mathrm{CO}_{2}$ fluxes from subtropical plantation coniferous ecosystem, Sci. China Ser. D, 149, 99-109.

Lü, A. F., H. Q. Tian, M. L. Liu, J. Y. Liu, and J. M. Melillo (2006), Spatial and temporal patterns of carbon emissions from forest fires in China from 1950 to $2000, J_{-}$Geophys. Res., III, D05313, doi:10.1029/ 2005JD006198

$\mathrm{Lu}, \mathrm{C}$. Q. (2009), Study of atmospheric nitrogen deposition and terrestrial ecosystem carbon cycle in China, Ph.D. diss., 204 pp, Chinese Acad. of Sci., Beijing.

Lu, C. Q., and H. Q. Tian (2007), Spatial and temporal patterns of nitrogen deposition in China: Synthesis of observational data, J. Geophys. Res. 112, D22S05, doi:10.1029/2006JD007990.

Lu, F., X. Wang, B. Han, Z. Quyang, X. Duan, H. Zheng, and H. Miao (2009), Soil carbon sequestrations by nitrogen fertilizer application, straw return and no-tillage in China's cropland, Global Change Biol., 15, 281-305, doi:10.1111/j.1365-2486.2008.01743.x.

Magnani, F., et al. (2007), The human footprint in the carbon cycle of temperate and boreal forests, Nature, 447, 849-851, doi:10.1038 nature 05847

McGuire, A. D., J. M. Melillo, D. W. Kicklighter, and L. A. Joyce (1995) Equilibrium responses of soil carbon to climate change: Empirical and process-based estimates, J. Biogeogr., 22, 785-796, doi:10.2307/2845980.

McGuire, A. D., et al. (2001), Carbon balance of the terrestrial biosphere in the twentieth century: Analyses of $\mathrm{CO}_{2}$, climate and land-use effects with four process-based ecosystem models, Global Biogeochem. Cycles, $15(1)$ 183-206, doi:10.1029/2000GB001298.

McGuire, A. D., et al. (2004), Land cover disturbances and feedbacks to the climate system in Canada and Alaska, in Land Change Science: Observing, Monitoring, and Understanding Trajectories of Change on the Earth's Surface, edited by G. Gutman et al., pp. 139-161, Kluwer, Dordrecht, Netherlands.

McGuire, A. D., et al. (2010), An analysis of the carbon balance of the Arctic Basin from 1997 to 2006 , Tellus, Ser. B, 62, 455-474, doi: $10.1111 / \mathrm{j} .1600$ 0889.2010.00497.x
Melillo, J. M., et al. (1993), Global climate change and terrestrial net primary production, Nature, 363, 234-240, doi:10.1038/363234a0.

Melillo, J. M., et al. (2009), Indirect emissions from biofuels: How important?, Science, 326, 1397-1399, doi:10.1126/science.1180251.

Mu, Q., M. Zhao, S. W. Running, M. Liu, and H. Tian (2008), Contribution of increasing $\mathrm{CO}_{2}$ and climate change to the carbon cycle in China's ecosystems, J. Geophys. Res., 113, G01018, doi:10.1029/2006JG000316.

Pan, Y., T. Luo, R. Birdsey, J. Hom, and J. Melillo (2004), New estimates of carbon storage and sequestration in China's forests: Effects of ageclass and method on inventory-based carbon estimation, Clim. Change 67, 211-236, doi: 10.1007/s10584-004-2799-5.

Peters, W., et al. (2007), An atmospheric perspective on North American carbon dioxide exchange: CarbonTracker, Proc. Natl. Acad. Sci. U. S. A. 104, 18,925-18,930, doi:10.1073/pnas.0708986104.

Piao, S., et al. (2009), The carbon balance of terrestrial ecosystems in China, Nature, 458, 1009-1013, doi:10.1038/nature07944.

Reich, P. B., et al. (2006), Nitrogen limitation constrains sustainability of ecosystem response to $\mathrm{CO}_{2}$, Nature, 440, 922-925, doi:10.1038 nature04486.

Ren, W., et al. (2007a), Influence of ozone pollution and climate change on grassland ecosystem productivity across China, Environ. Pollut., 149 327-335, doi: 10.1016/j.envpol.2007.05.029.

Ren, W., et al. (2007b), Effects of tropospheric ozone pollution on net primary productivity and carbon storage in terrestrial ecosystems of China, J. Geophys. Res., H12, D22S09, doi:10.1029/2007JD008521.

Ren, W., et al. (2011), Spatial and temporal patterns of $\mathrm{CO}_{2}$ and $\mathrm{CH}_{4}$ fluxes in China's croplands in response to multifactor environmental changes, Tellus, Ser. B, doi:10.1111/j.1600-0889.2010.00522.x, in press.

Sitch, S., P. M. Cox, W. J. Collins, and C. Huntingford (2007). Indirect radiative forcing of climate change through ozone effects on the land-carbon sink, Nature, 448, 791-794, doi:10.1038/nature06059.

Smith, P. (2005), An overview of the permanence of soil organic carbon stocks: Influence of direct human-induced, indirect and natural effects, Eur. J. Soil Sci., 56, 673-680, doi:10.1111/j.1365-2389.2005.00708.x.

Sokolov, A. P., et al. (2008), Consequences of considering carbon-nitrogen interactions on the feedbacks between climate and the terrestrial carbon cycle, J. Clim., 21, 3776-3796, doi:10.1175/2008JCLI2038.1.

Sun, W., Y. Huang, W. Zhang, and Y. Yu (2009), Estimating topsoil SOC sequestration in croplands of eastern China from 1980 to 2000, Aust. J. Soil Res., 47, 261-272, doi:10.1071/SR08132.

Thornton, P. E., J.-F. Lamarque, N. A. Rosenbloom, and N. M. Mahowald (2007), Influence of carbon-nitrogen cycle coupling on land mode response to $\mathrm{CO}_{2}$ fertilization and climate variability, Global Biogeochem. Cycles, 21, GB4018, doi:10.1029/2006GB002868.

Thornton, P. E., et al. (2009), Carbon-nitrogen interactions regulate climate-carbon cycle feedbacks: Results from an atmosphere-ocean general circulation model, Biogeosciences, 6, 2099-2120, doi:10.5194/bg-62099-2009.

Tian, H. Q., et al. (1998), Effect of interannual climate variability on carbon storage in Amazonian ecosystems, Nature, 396, 664-667, doi:10.1038/ 25328.

Tian, H. Q., et al. (2003), Regional carbon dynamics in monsoon Asia and its implications for the global carbon cycle, Global Planet. Change, 37, 201-217.

Tian, H. Q., et al. (2008), Forecasting and assessing the large-scale and long-term impacts of global environmental change on terrestrial ecosystems in the United States and China, in Real World Ecology: Large-Scale and Long-Term Case Studies and Methods, edited by S. Miao, S. Carstenn, and M. Nungesser, pp. 235-266, Springer, New York.

Tian, H. Q., G. S. Chen, C. Zhang, J. M. Melillo, and C. A. S. Hall (2009), Pattern and variation of C:N:P ratios in China's soils: A synthesis of observational data, Biogeochemistry, doi:10.1007/s10533-009-9382-0.

Tian, H. Q., et al. (2010a), Model estimates of ecosystem net Primary productivity, evapotranspiration, and water use efficiency in the southern United States during 1895-2007, For. Ecol. Manage., 259, 1311-1327, doi:10.1016/j.foreco.2009.10.009.

Tian, H., et al. (2010b), Spatial and temporal patterns of $\mathrm{CH}_{4}$ and $\mathrm{N}_{2} \mathrm{O}$ fluxes in terrestrial ecosystems of North America during 1979-2008 Application of a global biogeochemistry model, Biogeosciences, 7 , 2673-2694, doi:10.5194/bg-7-2673-2010.

Townsend, A. R., B. H. Braswell, E. A. Holland, and J. E. Penner (1996) Spatial and temporal patterns in terrestrial carbon storage due to deposition of anthropogenic nitrogen, Ecol. Appl., 6, 806-814, doi:10.2307/2269486.

Trenberth, K. E., et al. (2007), Observations: Surface and atmospheric climate change, in Climate Change 2007: The Physical Science Basis. Contribution of Working Group I to the Fourth Assessment Report of the Intergovernmental Panel on Climate Change, edited by $\mathrm{S}$. Solomon et al., pp. 237-336, Cambridge Univ. Press, Cambridge, U. K. 
Wang, X. K., M. William, Z. Feng, and Y. Zhu (2007), Ground-level ozone in China: Distribution and effects on crop yields, Environ. Pollut., 147, 394-400, doi:10.1016/j.envpol.2006.05.006.

Wu, J. (2006), Carbon budget of the broadleaved Korean pine forest in Changbai Mountain, Ph.D. diss., Chinese Acad. of Sci., Shenyang, China.

Xiao, X., et al. (1998), Transient climate change and net ecosystem production of the terrestrial biosphere, Global Biogeochem. Cycles, 12, 345-360, doi: $10.1029 / 98 \mathrm{~GB} 01035$.

$\mathrm{Xu}, \mathrm{L}$. (2006), Observation and simulation of the net ecosystem exchange over alpine meadow in the Qinghai-Tibet Plateau and its responses to global change, $\mathrm{Ph} . \mathrm{D}$. diss., Chinese Acad. of Sci., Beijing.

$\mathrm{Xu}-\mathrm{Ri}$, and I. C. Prentice (2008), Terrestrial nitrogen cycle simulation with a dynamic global vegetation model, Global Change Biol., 14, 1745-1764, doi:10.1111/j.1365-2486.2008.01625.x.

Zaehle, S., and A. D. Friend (2010), Carbon and nitrogen cycle dynamics in the $\mathrm{O}-\mathrm{CN}$ land surface model: 1. Model description, site-scale evaluation, and sensitivity to parameter estimates, Global Biogeochem. Cycles, 24, GB1005, doi:10.1029/2009GB003521.

Zaehle, S., P. Friedlingstein, and A. D. Friend (2010a), Terrestrial nitrogen feedbacks may accelerate future climate change, Geophys. Res. Lett., 37, L01401, doi:10.1029/2009GL041345.

Zaehle, S., A. D. Friend, P. Friedlingstein, F. Dentener, P. Peylin, and M. Schulz (2010b), Carbon and nitrogen cycle dynamics in the $\mathrm{O}-\mathrm{CN}$ land surface model: 2 . Role of the nitrogen cycle in the historical terrestrial carbon balance, Global Biogeochem. Cycles, 24, GB1006, doi:10.1029/ 2009GB003522.
Zarin, D. J., et al. (2005), Legacy of fires slows carbon accumulation in Amazonian forest regrowth, Front. Ecol. Environ, 3(7), 365-369, doi:10.1890/1540-9295(2005)003[0365:LOFSCA]2.0.CO;2.

Zhang, C., et al. (2007), Impacts of climatic and atmospheric changes on carbon dynamics in the Great Smoky Mountains National Park, Environ. Pollut., 149, 336-347, doi:10.1016/j.envpol.2007.05.028.

Zhang, L. M. (2006), Ecophysiological controls on seasonal variations of ecosystem carbon exchange of typical forest ecosystems along NSTEC, Ph.D. diss., Chinese Acad. of Sci., Beijing.

Zhang, Y., G. Zhou, D. Q. Wen, and Q. M. Zhang (2002), Biomass dynamics of the Castanopsis chinensis-Schima superba-Cryptocarya coninna community of monsoon evergreen broad-leaved forest in Dinghushan Reserve, Trop. Subtrop. For. Ecosys., 9, 10-17.

Zhuang, Q., et al. (2006), $\mathrm{CO}_{2}$ and $\mathrm{CH}_{4}$ exchanges between land ecosystems and the atmosphere in northern high latitudes over the 21 st century, Geophys. Res. Lett., 33, L17403, doi:10.1029/2006GL026972.

G. Chen, M. Liu, C. Lu, S. Pan, W. Ren, H. Tian, X. Xu, and C. Zhang, International Center for Climate and Global Change Research, Auburn University, Auburn, AL 36849, USA. (tianhan@auburn.edu)

D. Kicklighter and J. Melillo, The Ecosystem Center, Marine Biological Laboratory, Woods Hole, MA 02543, USA.

J. Liu, Institute of Geographical Sciences and Natural Resources Research, Chinese Academy of Sciences, Beijing 100101, China.

S. Running, College of Forestry and Conservation, University of Montana, Missoula, MT 59812, USA. 